\title{
OSMANLI YARGI TEŞKİLATINDA NAİB
}

\author{
Arş. Gör. Betül KAYAR
}

\section{ÖZET}

Makalemizin konusunu, Osmanlı Devleti adli teşkilatı içerisinde görev alan naib teşkil etmektedir. Osmanlı Devleti adli teşkilatının temeli olan kadı hakkında çok çeşitli çalışmalar mevcut iken kadının en önemli yardımcısı olan naib hakkında çalışma sayısı pek fazla değildir. Adli işlerinin yanı sıra idari görevlerinde de kadıya yardımcı olan naib, kadı yerine atanabilmesiyle de ayrıca öneme sahiptir. Çalışmamızda şeriye sicilleri, mühimme defterleri, kanunnameler ve ruznamçelerden faydalanılarak naiblik kurumu hakkında teorik çıkarımlarda bulunulmuştur. Varmış olduğumuz sonuçları şu şekilde özetleyebiliriz: Naibler kadının yardımcısı sıfatıyla adli ve idari işlerin yürütülmesinde kadının işlerini hızlandırmış ve kolaylaştırmış olup adaletin tesisinde önemli rol oynamıştır. Fakat ilerleyen dönemlerde çeşitli amaçlarla kadıların yerine atanmaları ve bu uygulamanın sıklaşması adli teşkilatın yozlaşmasında etkili olmuştur. Naiblik kurumu, usulüne uygun şekilde yürütüldüğünde ise adli teşkilata verim sağlamıştır.

Anahtar Kelimeler: Osmanlı Devleti, Adli Teşkilat, Kadı Yardımcısı, Hâkim Yardımcısı, Naib.

Ankara Yıldırım Beyazit Üniversitesi Hukuk Fakültesi, Hukuk Tarihi Anabilim Dalı, betul.isik@hotmail.com, ORCID ID: 0000-0002-0640-0457 (Geliş Tarihi: 21.06.2019 - Kabul Tarihi: 31.07.2019). 


\title{
“NAIB” IN THE OTTOMAN JUDICIAL SYSTEM
}

\begin{abstract}
The subject of this study is the "naib" within the judicial organization of the Ottoman Empire. While there is a wide variety of studies on the "kadi" which has the main role in the Ottoman judicial system, it seems that there are not many studies about "naib" though it is the most important assistant of the kadi. Assisting kadi in both his judicial and administrative duties, "naib" also has a special importance as it can be appointed as kadi to fulfill his mission. In this study, theoretical inferences about the naibship were made by making use of kadi records, books of mühimme, codes and ruznamçe registers. Our conclusions can be summarized as follows: The naibs as kadi's assistant, had accelerated and facilitated kadi's work in the execution of judicial and administrative affairs and played an important role in the establishment of justice. However, in the following period their appointments instead of kadis for various purposes and especially the increase in this practice became effective in the degeneration of the judicial organization. Nevertheless, naibship seems to be provided efficiency in the judicial system when it was duly carried out.
\end{abstract}

Keywords: The Ottoman Empire, Judicial System, Assistant of Kadi, Assistant of Judge, Naib. 


\section{GİRiş}

Osmanlı Devleti yargı teşkilatı, kendinden önceki İslam devletlerinin yargı teşkilatlarına benzerlik göstermekle birlikte çağının şartlarına göre gelişmiş ve farklılık arz etmiştir. Özellikle Abbasi ve Selçuklu Devletleri'nin adli yapısı ile benzerlik gösteren Osmanlı yargı teşkilatı, kadıların görev almış olduğu şeriye mahkemelerinin ön plana çıkması ile diğer devletlerden ayrılmıştır. Divan-1 Hümayun, vezir divanları, kazasker divanları, paşa divanları gibi çeşitli kazai merciiler bulunmakla birlikte hukuki uyuşmazlıklar esas olarak şeriye mahkemelerinde çözülmüştür. Şeriye mahkemelerinde kadılar yargı görevlerini icra ederken naib, şuhüd'ül hal, kassam, kâtip gibi çok sayıda yardımcısı bulunmuştur'. Bunlar arasında en çok öne çıkan görevli ise naib olmuştur.

Naib, Osmanlı adli teşkilatında önemli bir yere sahip olduğu gibi Türk ve İslam devletlerinde de hem adli hem idari alanda yer almış önemli bir görevlidir. "Birinin yerine geçen, vekil" 2 anlamına gelen naib, ilk olarak devlet idaresindeki görevlilerin yerine geçici süre ile bakan kişiler hakkında kullanılmış olup hükümdar vekili olmaları sebebiyle vezirlere naib-i saltanat denilmiştir. Vali gibi taşra idarecilerinin yanı sıra müderris, kadı, müftü gibi kamu görevlileri kendi yerlerine naib atamıştır. Bunun dışında kadılar için de hükümdarın vekili olarak yargı görevini yürütmeleri sebebiyle naib ifadesi kullanılmıştır³.

Konu ile ilgili literatürde değerli çalışmalar mevcut olmakla birlikte başlı başına naiblik kurumunun incelendiği çalışma sayısı azdır. Bu çalışmalardan, Aydoğan Demir'in 1994 tarihli Bayburt Ulu Camii'nde Bir Osmanlı Ferman Kitabesi-Osmanlı Devleti'nde Naiplik çalışması, naiblik kurumu ile ilgili önemli bilgiler vermektedir. Söz konusu çalışmada Osmanlı Devleti’nde kadı naibinin üzerinde durulmuş, şeriye sicil kayıtlarından faydalanılmıştır. Hamiyet Sezer Feyzioğlu ve Selda Kılıç tarafından hazırlanan 2005 tarihli Tanzimat Arifesinde Kadılık-Naiplik Kurumu adlı çalışmada, Osmanlı'nın son dönemlerinde yaşanan kurumlardaki bozulma, kadı ve naib açısından incelenmiştir. İsmail Hakkı Uzunçarşılı'nın Osmanlı Devleti’nin İlmiye Teşkilatı adlı kitabı ile Mehmet İpşirli’nin

Aydın, Mehmet Akif "Osmanlıda Hukuk: İhsanoğlu, Ekmeleddin" (Editör) (1994) Osmanlı Devleti ve Medeniyeti Tarihi, 1. Bası, İstanbul, Yıldız Matbaacılık, s. 391-404.

2 Devellioğlu, Ferit (2017) Osmanlıca-Türkçe Ansiklopedik Lugat, 33. Baskı, Ankara, Aydın Kitabevi Yayınları, s. 937.

3 Cin, Halil/Akgündüz, Ahmed (1995) Türk Hukuk Tarihi 1. Cilt Kamu Hukuku, 3. Baskı, İstanbul, Osmanlı Araştırmaları Vakfi Yayınları, s. 275. 
Türkiye Diyanet Vakfı İslam Ansiklopedisi'nde yer alan naib başlıklı maddesi, yine Mehmet Zeki Pakalın'ın Osmanlı Tarih Deyimleri ve Terimleri Sözlügü̈nde yer alan naip maddesi, naiblik kurumu ile ilgili önemli bilgiler içeren diğer çalışmalardır.

Çalışmamız ise naiblik kurumunun Osmanlı Devleti yargı teşkilatı içerisindeki konumunu, görev ayrımlarını, atama ve azledilme prosedürleri ve bu prosedürlere uyulup uyulmadığını başta şeriye sicilleri ve kanunnameler olmak üzere mühimme defterleri ve ruznamçe gibi farklı kaynaklardan da incelemesiyle diğer çalışmalardan ayrılmaktadır. Naib, adli teşkilat içerisinde yer almakla birlikte ne gibi görevler icra etmiştir? Bir mahkemede birden fazla naib bulunabilmiş midir? Bulunması halinde görevleri ayrılmış mıdır? 17. yüzyıl itibariyle adli teşkilatın bozulmasında naiblik kurumunun etkisi nasıl olmuştur? Çalışmamızda cevap vermeye çalışacağımız sorulardan bazıları bu şekildedir.

\section{OSMANLI DEVLETİ YARGI TEŞKİLATI}

Osmanlı Devleti kurumları incelenirken genel olarak klasik dönem ve Tanzimat sonrası dönem olmak üzere ikili bir ayrım yapmak gerekmektedir. Klasik dönem, Osmanlı Devleti’nin kuruluşundan itibaren başlayan, Osmanlı Devleti’nin ayırıcı özelliklerinin oluştuğu, Osmanlı uygarlığının geliştiği ve devletin kurumlaştığ 1 dönemdir. Bu süreçte devletin gerileme sürecine girmesiyle birlikte çeşitli iyileştirme girişimlerinde bulunulmuş fakat Tanzimat dönemine kadar sistemli bir yenileşme hareketi gerçekleşememiştir ${ }^{4}$. Tanzimat dönemi ise 1839 yılında Sultan Abdülmecid tarafından ilan edilen Tanzimat Fermanı ile başlamış ve bu süreçte Osmanlı hukuk ve yargı sistemi köklü değişikliklere uğramıştır ${ }^{5}$.

\section{A. KLASİK DÖNEM OSMANLI YARGI TEŞKILAATI}

Osmanlı Devleti'nin Tanzimat öncesi hukuk sistemi hakkında, İslam hukukunun birebir uygulaması olduğu yönünde fikirler olduğu gibi, İslam hukukunun sinırlı bir uygulaması ile birlikte aslında kendine özgü bir hukuk sistemi olduğu yönünde görüşler de mevcuttur. Bununla birlikte Osmanlı

4 Yurtseven, Yılmaz (2006) “Osmanlı Devleti’nde Siyasal İktidarın Meşruluk Temelleri”, (Yayımlanmamış Doktora Tezi), Selçuk Üniversitesi Sosyal Bilimler Enstitüsü, s. 53.

5 Akyılmaz, Gül (2015) Siyasi Tarih, 1. Baskı, Ankara, Seçkin Yayınevi, s. 181-197. 
hukuk sistemi, kendinden önce hüküm süren Türk ve İslam devletlerinin uyguladığı hukuk sistemlerinin benimsenmesi ve devletin ihtiyaçları çerçevesinde gerek duyulan değişikliklerin de yapılması ile oluşan bir hukuk sistemidir. Başka bir deyişle Osmanlı hukuku, şer'i hukuk ve örfi hukuktan oluşmaktadır ${ }^{6}$. Şer’i hukuktan kasıt, Kuran, sünnet, icma ve kıyastan oluşan İslam hukuk kurallarıdır $^{7}$. Örfi hukuk ise padişahlar tarafından verilen emir ve fermanlarla oluşan kurallar bütünüdür'.

Klasik dönem Osmanlı yargı teşkilatı yine Abbasi ve Selçuklu Devletleri'nde bulunan yargı kurumlarıyla benzerlik taşımaktadır. Bununla birlikte söz konusu adli kurumlar Osmanlı bünyesinde yeniden şekillenmiş, o günün koşulları çerçevesinde gelişme göstermiştir. Bu anlamda Osmanlı Devleti’nde kadıların atama, nakil, azil gibi özlük işlemleriyle ilgilenen ve yargı teşkilatının başı kabul edilen kazasker, Abbasi Devleti'nde ortaya çıkan kadi'l-kudatlık kurumunun devamı niteliğindedir. Yine Abbasiler'de halkın şikayetlerini inceleyerek karara bağlayan Divan-1 Mezalim, Osmanlı'da devletin en yüksek kurul organı olup yarg1lama görevi de yürüten Divan-ı Hümayun'un temelini oluşturmaktadır. Fakat belirtmek gerekir ki, Osmanlı Devleti’nde en yüksek fetva makamı olan Şeyhülislam, bu niteliğiyle daha önceki Türk İslam devletlerinde yer almamıştır?

Divan-1 Hümayun, kadılar tarafından verilen kararları temyiz mahkemesi gibi denetlemesi veya doğrudan kendisine dilekçe ile başvurulması halinde hukuki uyuşmazlıkları çözmesi bakımından önemli bir yargı mercii olmuştur. Uyuşmazlıkların çözümünde söz konusu divanda yer alan Rumeli ve Anadolu kazaskerleri rol almıştır. Duruşmalı veya duruşmasız olarak yapılan yargılama sonucu kadı kararları; düzeltilmesi için ilgili kadıya veya başka kadıya gönderilebildiği gibi divan tarafından kesin hüküm de verilebilmiştir. Bunun dışında veziriazamın başkanlığını yaptığı İkindi Divanı, Çarşamba ve Cuma Divanları da yargılama faaliyetleri yürütmüştür. İkindi Divanı’nda da şer’i ve örfi davalar dinlenmiş ve halk İkindi

Aydın, (1994) s. 375-376.

Cin, Halil/Akyılmaz, Gül (2013) Türk Hukuk Tarihi, 5. Baskı, Konya, Sayram Yayınları, s. 50-63. Bu dört kaynak bütün İ̀lam hukukçuları tarafindan İslam hukukunun kaynağı olarak kabul edilmiş̧ir ve asli kaynaklar olarak da adlandırılmaktadır. Bunun dışında tali kaynaklar olarak adlandırılan ve İslam hukukçuları arasında hukuk kaynağı olup olmadıkları tartışmalı olan istihsan, maslahat gibi kaynaklar da mevcuttur. Ekinci, Ekrem Buğra (2008) Osmanlı Hukuku, 1. Baskı, İstanbul, Arı Sanat Yayınevi, s. 106-123.

8 Örfi hukuk terimi ilk olarak Fatih döneminde Tursun Bey tarafindan kullanılmış olsa da örfi hukuk uygulamasının Osmanlı Devleti öncesinde de var olduğu tarihi kaynaklardan anlaşılmaktadır. Aydın, Mehmet Akif (2014) Türk Hukuk Tarihi, 12. Bası, İstanbul, Beta, s. 66-67.

9 Cin/Akylmaz, s. 165-170. 
Divanı'na şikâyet dilekçeleri ile başvurabilmiştir. Çarşamba Divanı'na İstanbul, Galata, Eyüp ve Üsküdar kadıları katılmış ve halkın şikayetlerini dinlemiştir. Cuma Divanı'na ise kazaskerler katılmış olup şer'i ve örfi hukuk alanındaki uyuşmazlıkları çözümlemiştir. Yine Yeniçeri ağasının suç işleyen yeniçerileri yargıladığı Ağa Divanı, bir diğer yargı organı olmuştur. Son olarak taşra teşkilatında eyaletlerin başında bulunan beylerbeyinin başkanlık ettiği, Divan-1 Hümayun'un benzeri niteliğinde bir Paşa Divanı bulunmakta olup eyalet halkının şikayetleri dinlenmiş$\operatorname{tir}^{10}$.

Klasik dönem Osmanlı yargı teşkilatı içinde bulunmamakla birlikte şeriye mahkemeleri haricinde uyuşmazlıkları çözen iki mahkeme daha mevcuttur. Bunlar gayrimüslimlerin belirli konular hakkında uyuşmazlıklarının görüldüğü cemaat mahkemeleri ve yabancı devletlere verilen kapitülasyonlar çerçevesinde görev yapan konsolosluk mahkemeleridir ${ }^{11}$.

Osmanlı yargı teşkilatında şeriye mahkemeleri, İslam hukukuna uygun olarak tek hakimli ve tek dereceli şekilde oluşturulmuştur ${ }^{12}$. Yine diğer İslam devletlerinde olduğu gibi Osmanlı Devleti'nde de yargı yetkisi, şeriye mahkemelerinde kadılar tarafından icra edilmiştir ${ }^{13}$. Kadılar, Osmanlı yargı örgütünün temelini oluşturmuş olduğundan kadıların tahsiline büyük önem verilmiştir. Buna göre bir kişinin kadı olarak atanabilmesi için mutlaka medrese mezunu olması şartı aranmıştır ${ }^{14}$. Herhangi bir medreseden mezun olmak yeterli sayılmamış, belirli bazı medreselerden eğitim almış olma koşulu getirilmiştir. Buna göre bir kimsenin kadı olabilmesi için önce taşrada bulunan Hariç ve Dahil adı verilen medreselerden mezun olmas1, sonrasinda Muhsile-i Sahn ve Sahn-1 Seman Medreselerine devam etmesi gerekmiştir. Bu medreselerden başarı ile mezun olarak icazet alan kimseler "mülazım"15 olmuş ve kaza kadılıklarına atanma hakkı kazanmıştır. Öğrenimine

\footnotetext{
Aydın (2014) s. 85-86; Cin/Akylmaz, s.148-149, 155, 159.
}

Ǘçok/Mumcu/Bozkurt, s. 244.

12 İslam hukukunda toplu hakimli mahkemeler yasaklanmış değildir. Fakat uygulamada tek hakimli mahkemeler davaları karara bağlamıştır. Cin/Akyılmaz, s. 168, s. 174; Anıl, Yaşar Şahin (1993) Osmanlı'da Kadılık, 1. Basım, İstanbul, İletişim Yayınları, s. 19.

13 Anıl, s. 32; Ortaylı, ílber (2016) Hukuk ve İdare Adamı Olarak Osmanlı Devleti'nde Kadı, 2. Baskı, İstanbul, Kronik, s. 24.

14 Halaçoğlu, Yusuf (2014) XIV-XVII Yüzyıllarda Osmanlılarda Devlet Teşkilatı ve Sosyal Yapı, 7. Baskı, Ankara, Atatürk Kültür, Dil ve Tarih Yüksek Kurumu Türk Tarih Kurumu Yayınları, s. 128; Fendoğlu, Hasan Tahsin (2000) Türk Hukuk Tarihi, 1. Baskı, İstanbul, Filiz Kitabevi, s. 386; Anıl, s. 64. Osmanlı Devleti’nde kadılar ve ilmiye sınıfı dışında diğer hiçbir kamu görevlisi sınıfı için bu şekilde eğitim şartı aranmamış olması, kadılık müessesesine verilen önemi gözler önüne sermektedir. Cin/Akyllmaz, s.172.

15 Mülazemet hakkında ayrıntılı bilgi için bakınız: Aykanat, Mehmet (2018) "Klasik Dönemde Osmanlı Devleti’nde Hâkim Adaylı̆̆ı: Mülazemet”, Türkiye Adalet Akademisi Dergisi, Sayı: 34, s. 165-188. 
devam ederek Kanuni döneminde kurulan yüksek dereceli medreselerden mezun olmaları halinde ise yüksek dereceli kadılıklara tayin olma hakkı kazanmışlardır ${ }^{16}$.

$\mathrm{Bu}$ şekilde zorlu bir tahsil sürecinden geçen kadılar, görev almış oldukları kazalarda hem şer’i hem örfi davalara bakarken diğer yandan idarecilik de yapmışlardır. Bu anlamda yargı görevi dışında nikah kıymak, miras taksim etmek, çeşitli sözleşmeleri düzenlemek, pazarları ve vakıfları denetlemek gibi çok sayıda görevi olmuştur. Kadılar, çok çeşitli ve fazla sayıdaki bu görevlerini yerine getirirken başta naib olmak üzere kâtip, şuhüd’ül hal, muhzır (mübaşir), kassam, tezkiye memurları gibi görevliler de kadılara yardımcı olmuştur ${ }^{17}$.

\section{B. TANZIMAT DÖNEMİ OSMANLI YARGI TEŞKİLATI}

Tanzimat Fermanı ile birlikte başlayan kanunlaştırma hareketleri, yargı teşkilatı bakımından da yenilikler getirmiş olup Tanzimat sonrası dönemde birçok yeni mahkeme kurulmuştur. Şeriye mahkemeleri görevlerini sürdürmeye devam ederken, bu mahkemelerin kararlarını temyiz merci sıfatıyla incelemek üzere 1862 yllında Meclis-i Tetkikat-1 Şer'iyye kurulmuştur. Yine 1864 tarihli Vilayet Nizamnamesi ile nizamiye mahkemeleri kurulmuştur. İlk aşamada görev alanları oldukça sınırlı olsa da ilerleyen dönemde, şer’i konular dışındaki tüm uyuşmazlıklar, nizamiye mahkemelerinin görev alanına girmiştir ${ }^{18}$. Şeriye mahkemelerindeki tek hakimli uygulama, nizamiye mahkemelerindeki çok hakimli yeni sistem ile artık değişmiştir. Ayrıca nizamiye mahkemelerinde gayrimüslimlerin de hâkim olarak görev alması önemli bir yeniliktir ${ }^{19}$.

Yeni kabul edilen ceza kanunnamesinin uygulanması amacıyla ilk olarak İstanbul'da Meclis-i Tahkikat adıyla bir kurul oluşturulmuş, 1854 yılından itibaren söz konusu kurul, eyalet merkezlerinde de açılmıştır. Meclis-i Tahkikat, ceza işleriyle ilgilenmesinin yanı sıra belirli günlerde toplanarak ceza da-

\footnotetext{
Cin/Akylmaz, s.171-172.
}

Üçok, Coşkun/Mumcu, Ahmet/Bozkurt, Gülnihal (2017) Türk Hukuk Tarihi, 19. Baskı, Ankara, Turhan Kitabevi, s. 243-244; Cin/Akyılmaz, s.175-179.

18 Tanzimat döneminde kurulan nizamiye mahkemeleri ile şeriye mahkemeleri arasındaki yetki ayrımı tam olarak belirlenememiş ve iki mahkeme arasındaki bu ihtilaf, uzun süre giderilememiştir. Özellikle idam cezasının söz konusu olduğu vakıalarda şeriye mahkemesinden de aynı şekilde karar çıkmadığı sürece nizamiye mahkemelerinin vermiş olduğu idam kararları uygulanamamıştır. Ayrıntılı bilgi için bakınız: Kılınç, Ahmet (2011) ‘İdam Cezasının Tanzimat Dönemi Osmanlı Hukukundaki Görünümüne İlişkin Birkaç Kaynak ve Bu Kaynakların Tahlili', Türk Hukuk Tarihi Araştırmaları, Sayı: 11, s. 33-62.

19 Cin/Akyılmaz, s.184-188. 
valarına da bakmıştır. Bu bağlamda ceza davaları şeriye mahkemelerinin görev alanından çıkmış ve toplu mahkeme niteliğindeki bu mahkemelerde görülmeye başlanmıştır. Kurulun vermiş olduğu kararlar kesin olup yalnızca idam cezaları ilk olarak Meclis-i Ahkam-1 Adliye'ye gönderilmiş, burada uygun bulunması halinde padişah onayına sunulmuştur ${ }^{20}$.

1840 yılı itibariyle ticari davalara bakmak üzere ayrı ticaret mahkemeleri oluşturulmuştur. İlk olarak İstanbul'da Ticaret Nezareti'ne bağlı şekilde Ticaret Meclisi kurulmuş, daha sonra karma ticaret mahkemeleri oluşturulmuştur. Karma ticaret mahkemeleri, gayrimüslim tacirlerin de bu mahkemelerde hâkim statüsünde görev alması bakımından önem arz etmiştir. 1850 yılında Ticaret Kanunu, 1861 yllında ise Ticaret Yargllama Kanunu kabul edilmiş olup söz konusu kanunlar ile tüm tacirlerin uyuşmazlıklarına bakmakla görevli ve daha geniş yetkili ticaret mahkemeleri, bu mahkemelerin kararlarını istinaf derecesinde inceleyen Ticari Temyiz Mahkemesi kurulmuştur ${ }^{21}$.

Tanzimat Fermanı'nın ilanından kısa bir süre önce II. Mahmut tarafından kurulmuş olan Meclis-i Valay-1 Ahkam-1 Adliye ${ }^{22}$, Tanzimat Fermanı'nda, kanun taslaklarını hazırlamakla görevlendirilmiştir. Yine memurları yargılamak, devlet ile kişi arasındaki uyuşmazlıkları çözümlemekle görevli olan bu önemli kurul, temyiz mahkemesi görevini de yürütmüştür. Zaman içerisinde çeşitli değişimlere uğrayan kurul son olarak 1868 yılında Divan-1 Ahkam-1 Adliye ve Şuray-1 Devlet olmak üzere ikiye ayrılmıştır. Günümüz Yargıtay'ının temelini Divan-1 Ahkam-1 Adliye oluştururken, günümüz Danıştay'ının temelini de Şuray-1 Devlet teşkil etmektedir ${ }^{23}$.

\section{KLASIKK DÖNEM OSMANLI YARGI TEŞKILLATINDA NAİB}

Osmanlı Devleti'nde naib, adli teşkilat içerisinde yer almış bir kamu görevlisidir. Kadı yardımcılarından en önemlisi olan bu görevlinin nasıl bir eğitim aldığı, hangi şartlarla atandığı, hangi görevleri üstlendiği, karşılığında ne gibi bir ücret aldığı ve hangi hallerde azledildiği aşağıda incelenecektir.

\footnotetext{
Cin/Akylmaz, s.184-185.
}

Üçok/Mumcu/Bozkurt, s. 359-360.

Meclis-i Valay-1 Ahkam-1 Adliye hakkında ayrıntılı bilgi için bakınız: Seyitdanlığlu, Mehmet (1999) Tanzimat Devrinde Meclis-i Vala (1838-1868), 1. Bask1, Ankara, Atatürk Kültür, Dil ve Tarih Yüksek Kurumu Türk Tarih Kurumu Yayınları.

23 Cin/Akylmaz, s.189-190. 


\section{A. NAİBİN EĞİTİMİ}

Osmanlı Devleti'nde adli teşkilat görevlileri medreselerde yetiştirilmiş$\operatorname{tir}^{24}$. Naib de kadıdan sonra adli teşkilatın en önemli görevlisi olması sebebiyle eğitimi önemli olup bir kimsenin naib olabilmesi için öncelikle taşrada bulunan Hariç ve Dahil adlı medreselerden mezun olması şart koşulmuştur ${ }^{25}$. Bu bakımdan klasik dönem Osmanlı medreselerinden kısaca bahsetmemiz faydalı olacaktır.

Osmanlı Devleti'nde Selçuklu Devleti'nde de olduğu gibi önceleri, eğitim ve öğretim devletin faaliyetleri dışında olmuştur. Bunun sebebi, eğitim ve öğretimin bir dini görev, hayır işi olarak görülmesidir. Dolayısıyla bu dönemde diğer hayır işlerinde olduğu gibi eğitim ve öğretim faaliyetlerinde de vakıflar etkili olmuş, mektep ve medreseler vakıflar tarafından kurulmuş ve işletilmiştir ${ }^{26}$.

Medrese kelimesi Arapça olup "ders gösterilen yer” anlamına gelmekte$\operatorname{dir}^{27}$. Osmanlı Devleti'nde medreseler, sıbyan mektebinden sonra gelen orta, lise, yüksek okul ve üniversite eğitimine karşılık gelmiştir. Hariç medreseleri, İbtida-1 Hariç ve Hareket-i Hariç olmak üzere iki kısma ayrılmış olup orta okul seviyesindedir. Dahil medreseleri de İbtida-ı Dahil ve Hareket-i Dahil şeklinde ikiye ayrılmış olup lise seviyesindedir. Fatih devrinde kabul edilen esaslara göre, İptida-i Hariç medreselerinde; gereken hallerde alfabeden başlanarak okuma yazma öğretilmiş olup daha sonra ilk din bilgileri yani İlmihal, Kur'an, yazı, dört işleme kadar Aritmetik verilmiştir. Hariç ve Dahil medreselerinde ayrıca "Mukaddemat-1 Ulum” denilen gramer, sentaks, vaaz, iştikak, geometri, hesap, münazara ve mantık dersleri de verilmiştir ${ }^{28}$.

Hariç ve Dahil medreselerini başarı ile tamamlayan kişi, staj dönemine geçmiştir. Stajını da başarı ile tamamlayan ve sınavda başarılı olan kimseler; eğitimlerine devam etmeleri halinde kadı, etmemeleri halinde naib olarak görev yapabilmiştir ${ }^{29}$.

24 Cin/Akgündüz, s. 271.

25 Cin/Akyilmaz, s. 172.

26 Askeri eğitim ve yöneticilerin eğitimleri ise devlet tarafindan yürütülmüştür. Akkutay, Ülker (1984) Enderun Mektebi, Ankara, Gazi Üniversitesi Yayınlanı, s. 15.

27 Doğan, Recai (1997) "Osmanlı Eğitim Kurumları ve Eğitimde İlk Yenileşme Hareketlerinin Batılılaşma Açısından Tahlili”, Ankara Üniversitesi İlahiyat Fakültesi Dergisi, Cilt: 37, Sayi: 1, s. 409.

${ }^{28}$ İpşirli, Mehmet (2003) İslam Ansiklopedisi, "Medrese", Türkiye Diyanet Vakfı İslam Araştırmaları Merkezi, Cilt: 28, s. 327; Ekinci, Ekrem Buğra Prof. Dr. Ekrem Buğra Ekinci, "Osmanlı Medreseleri”, $<$ http://www.ekrembugraekinci.com/makale.asp?id=931>, s.e.t. 23.12.2018. Doğan, s. 411.

29 Cin/Akyılmaz, s. 172; Üçok/Mumcu/Bozkurt, s. 241. Hariç ve Dahil medreselerinde eğitimini tamamlayan bir kimse, Sahn-1 Seman ve Sahn-1 Süleymaniye medreselerine devam ederek başarı ile mezun olması halinde 
Ayrıca Osmanlı Devleti’nde medreselerin İslami kimliği sebebiyle yalnızca Müslümanlar bu mekteplere devam edebilmiştir ${ }^{30}$. Bu bilgi ve naiblerin medrese mezunu olması şartı, yalnızca Müslüman kimselerin naiblik yapabileceği sonucuna bizi ulaştırmaktadır.

\section{B. NAİBIN ATANMASI}

Osmanlı Devleti'nde naibler, kadılar tarafından atanmış olup bu işlemin tamamlanması için kadıaskerlerin onayı gerekmiştir. Rumeli ve Anadolu bölgelerine yapılan naib atama işlemleri, Anadolu ve Rumeli kazaskerleri tarafından onaylanırken İstanbul'a yapılan naib atama işlemlerini İstanbul kadısı onaylamıştır. Ruzmançelerde de naib atandığına dair kayıtlara rastlanılmıştır. Kadılar, naibler hakkındaki atama işlemlerini "mürasele"31 denilen yazı ile gerçekleştirmiştir ${ }^{2}$. Aşağıdaki şeriye sicil kaydı söz konusu müraseleye bir örnektir:

“... Mevlana Muslihiddin Efendi ... işbu sene ... Şile nahiyesi niyabeti sana tefviz olunmuşdur. Gerekdir ki ba'de'l-yevm nahiye-i merkumede icra-yı ahkam-ı şer'iyye eyleyüb cadde-i şer'den mütecaviz iş etmiyesin ve umur-ı mu'azzamada bu taraf ile müsşavere eyleyesin..." ${ }^{\text {33 }}$

Osmanlı Devleti'nde bir bölgeye tayin edilecek olan naibin, esasen o bölgeden olmaması kural iken 1838 tarihli Tarık-i İlmiye Mahsus Ceza Ka-

icazet almıştır. İcazet, mezun olan kimsenin müderrislik yapabileceği anlamına gelmiştir. Bu aşamadan sonra kişi, müderris veya kadı olmak için görev yapacağı yere göre Anadolu veya Rumeli Kazaskeri'nin ruznamesine mülazım olarak kaydolup sıra beklemiştir. Uzunçarşıll, İsmail Hakkı (2014) Osmanlı Devleti'nin İlmiye Teşkilatı, 4. Baskı, Ankara, Atatürk Kültür, Dil ve Tarih Yüksek Kurumu Türk Tarih Kurumu Yayınları, s. 55. İpşirli (2003) s. 327.

Müraselenin sözlük anlamı, resmi kadı mektubu şeklindedir. Devellioğlu, s. 856.

2 BOA 5 Numaralı Mühimme Defteri, Hüküm No: 282, s. 209; İnalckk, Halil (1967) “Adaletnameler”, Belgeler, Ankara, Türk Tarih Kurumu, Cilt: 2, Sayı: 3-4, s. 76; Demir, Aydoğan (1994) "Bayburt Ulu Camii'nde Bir Osmanlı Ferman Kitabesi, Osmanlı Devleti'nde Naiplik", Tarih ve Toplum, Sayı: 132, s. 44; Akman, s. 44; İpşirli, Mehmet (2006) İslam Ansiklopedisi, "Naib", Türkiye Diyanet Vakfı İslam Araştırmaları Merkezi, Cilt: 32, s. 312; Kuru, Levent (2016) "Kazasker Ruznamçelerine Göre 18. Yüzyılın İlk Yarısında Rumeli’de Kadılık Müessesesi”, (Yayımlanmamış Doktora Tezi), Marmara Üniversitesi Türkiyat Araştırmaları Enstitüsü, s. 92. Bayındır ise kadıların naib atayabilmesi için ayrıca yetkilendirilmiş olması gerektiğini belirtmektedir. Buna göre kadılar; naib tayin etme ve azletme yetkisine sahip olanlar, naib tayin etmeye yetkili fakat azletmeye yetkili olmayan ve naib tayin etmeye yetkili olmayan şeklinde üç gruba ayrılmaktadır. Ayrıntılı bilgi için bakınız: Bayındır, Abdulaziz (2015) İslam Muhakeme Hukuku, 2. Baskı, İstanbul, Süleymaniye Vakfi Yayinlari, s. 115-116.

33 Demir, s. 44; Şer'iye Sicilleri II, s. 164. 
nunname-i Hümayunu ile söz konusu yasak kaldırılmıştır ${ }^{34}$. Bununla birlikte söz konusu tarihten önce de bölge halkından naibler atandığına dair vakıalar mevcuttur. Buna göre 1810-1811 tarihli Trabzon şeriye siciline göre, Trabzon Sürmene kadılığına atanan Lütfullah Efendi, yerine yöre halkından Mehmed Sadık Efendi'yi naib olarak atamış olup daha sonra aynı yere kadı olarak atanan Kastamonulu Ahmed Nuri Efendi ve ondan sonra atanan İstanbullu Mehmed Said Efendi de aynı kişiyi kendisine naib olarak tayin etmiştir ${ }^{35}$.

Yine birtakım sebeplerle kadı atamasının gecikmesi durumunda, bölge valisi veya kaymakamı, adli işlerin aksamaması amacıyla, mahkeme görevlileri arasından bir kadı vekili tayin etmiştir. 22 Şubat 1810 tarihli buyrultu bu hususa örnektir: "Trabzon kadısı ... bu vakte kadar zuhur etmeyip ... vekâletine dair ... mürâsele-i şer'iyesi gelmediğinden ... ahkâm-ı şer'iyenin icrası ... vacip olduğundan şehrin kadısı veya vekâlet verdiği kişiyle ilgili mürâsele-i şer’iyesi ortaya çıkıncaya kadar ... seni 'kadı vekili' tayin ettim." ${ }^{\text {'36 }}$

Söz konusu buyrultudan altı ay kadar sonra 2 Ağustos 1810 tarihinde Anadolu Kazaskeri Mehmed Tahir Efendi tarafından gönderilen emirde ise Trabzon naibi olarak söz konusu kadı vekili tayin edilmiştir. Yine Trabzon ve Sürmene kadı naibi olan Hafız Mehmed Efendi'nin ölmesi üzerine, kadının yeni bir naib atamasına kadar Vali Mehmed Husrev Paşa tarafından, mahkeme başkatibi, naib vekili olarak atanmıştır. Bu gibi atamalar geçici olup vali tarafından atanan naiblerin mürasele-i şeriyesinin yollanması için derhal merkeze yazı yazılmıştır ${ }^{37}$.

$\mathrm{Bu}$ anlamda yerel yöneticiler tarafından geçici ve vekaleten de olsa naib atanmış olduğu ve bu kişilerin yöre halkından hatta mahkeme görevlileri arasından seçilmiş olduğu görülmektedir. Naiblerin mahkeme görevlileri arasın-

34 Akman, s. 44; Demir, s. 44. Naiblerin özellikle görev yapacağı bölgenin ulemasından atandığına dair görüşler de bulunmaktadır. Ortaylı, s. 45. Yine Arap şehirlerine atanan kadıların yerli halktan naib atayarak yörenin dilini bilen kimselerin yardımını almayı amaçladığı belirtilmektedir. İpşirli (2006) s. 312.

35 Saydam, Abdullah (2005) ‘Trabzon'un İdari Yapısı ve Yenileşme Zarureti (1793-1851)', Ankara Üniversitesi Osmanlı Tarihi Araştırma ve Uygulama Merkezi Dergisi, Sayı: 18, s. 300-301. 1567 tarihli bir başka kayııtta yerliden atanan naiblerin azledilmesi ve bundan sonra yerliden naib atanmaması hususunun emredilmiș olmaS1, daha erken tarihlerde de yerli halktan naib atanmış olduğunu göstermektedir: BOA 7 Numaralı Mühimme Defteri I, Hüküm No: 496, s. 254-256.

36 Saydam, s. 302.

3717 Ocak 1820 tarihli bir belgede, Anadolu Kazaskeri tarafından, kadı atanıncaya kadar görev yapması için bir naib atandığı, daha sonra görevlendirilen kadının da aynı kişiyi naibi olarak tayin ettiği görülmektedir. Saydam, s. 302-303. 
dan seçilmesi yargılama faaliyeti açısından olumlu iken aynı bölgenin idarecisi tarafından ve yöre halkı arasından seçilmesi, adaletin tecellisi bakımından olumsuz etki yaratmıştır. Bu durumun yaşandığına işaret eden bir fermanda "yerliden naib ve katip olmak memnu iken, yerliden olan Abdullah'in her gelen kadıya naib ve katip olup, ehl-i örf taifesi ile işbirliği yaparak reayaya zulm etmesi ve ilgilinin görevden alınması"ndan bahsedilmiştir ${ }^{38}$. IV. Mehmed dönemine ait olduğu düşünülen söz konusu ferman da daha önceki tarihlerde yasak olmasına rağmen yerliden naib atanmış olduğuna işaret etmektedir.

Osmanlı adli teşkilatında naibin vekaleten yürütmekte olduğu yargılama görevini, kadının icazeti olmadan bir başka naibe devredememesi kural olmuştur. Aşağıda yer vermiş olduğumuz Ebussuud Efendi'nin fetvası bu hususa işaret etmektedir:

"Soru: Zeyd-i naibin izniyle Amr bir kaziyyeyi istima edib hükm eylese hükmü nafiz olur mu?

El-cevap: Olmaz. Asıl kadıdan icazete mucaz değil ise." ${ }^{" 39}$

Söz konusu fetva çerçevesinde Osmanlı Devleti'nde kadının icazetinin olması halinde naiblerin kendi yerlerine naib atayabileceği bilgisine ulaşılmaktadır. Bu durum ise yargı yetkisinin kimler tarafından kullanıldığı bilgisinden devleti uzaklaştırarak merkezilik ilkesinin uygulanmasına zarar verebilecek bir husus olarak değerlendirilebilir.

Kadının tayin edilmiş olduğu kazanın büyük veya küçük olmasına göre naiblerin sayıları değişebilmiştir. Başka bir deyişle kadılar görev yüklerinin artmasına göre birden fazla sayıda naib atayabilmiştir ${ }^{40}$. Bu duruma en güzel örnek İstanbul kadılığıdır. İstanbul'un Osmanlı Devleti'nin başkenti olması dolayısıyla nüfus ve iş yoğunluğunun çok olması, İstanbul kadılığında çok fazla sayıda ve çeşitli görevlerde naibin görev yapması sonucunu doğurmuştur. İstanbul dışındaki diğer yörelerde de birden fazla naibin görevlendirilebilmiş olduğu yine kayıtlardan anlaşılmaktadır. Örneğin Harput yöresiyle ilgili yapılan bir çalışmada, şeriye sicillerinde Es-Seyyid Ahmed isimli bir naib hakkında "naib-i sani” şeklinde bahsedil-

\footnotetext{
Demir, s. 42.

Akman, s. 44.

Uzunçarşıll, s. 121.
} 
diği belirtilmiş ${ }^{41}$ olup bu durum belli bir adli işin takibi amacıyla birden fazla naibin görevlendirilebildiğine işaret etmektedir. Bununla birlikte mühimme kayitlarında geçen ve Sivas Beylerbeyine yazılan “...Artuk-abad kadısınun on iki naibi var diyü istima olınup vakı midur? Arz idesün..." ${ }^{\prime 2}$ şeklindeki ifade, Osmanlı'nın belli bir yörede gereğinden fazla naibin görevlendirilmiş olup olmadığını denetlediğine de işaret etmektedir.

Naibler göreve atanırken genellikle belirli süre veya belirli bir görev için atanmış olup naibi atamış olan kadının azledilmesi veya ölmesi halinde, naibin görevi sona ermemiştir. Osmanlı Devleti'nde istisnai de olsa otuz yıl gibi uzun sürelerle aynı yerde naiblik yapan kimseler mevcut olmuştur ${ }^{43}$. Bu duruma özellikle arpalık kazalarında rastlanılmıştır. Zira arpalığın tahsis edildiği kadılar değişse de naib olarak aynı kişiyi tayin edebilmişlerdir. Örneğin 1793 ve 1851 yılları arasında Trabzon'un idari yapısını inceleyen bir çalışmaya göre, Trabzon kadısı neredeyse hiç görev yerine gelmemiş ve yerine naib görevlendirmiştir. Belirtilen tarihler arasında kadı her yıl değişirken, naiblik daha çok üç kişi tarafından icra edilmiş olup nadiren bu üç kişi dışında biri naib olarak görevlendirilmiş veya kadının kendisi görev yerine intikal etmiştir ${ }^{44}$. Dolayısıyla aynı bölgede belirli üç kişinin altmış yıla yakın bir süreyle naiblik yapması, o bölgede yolsuzluklara kapı aralayabilmiştir. Bu durum yargı teşkilatındaki yozlaşmayı da beraberinde getirmiştir ${ }^{45}$.

Bir başka örnekte ise Balya isimli bölgede görev yapmakta olan naib, haksız işler yürüten bazı kimselere göz yummaması sebebiyle, bu kimselerin

41 Erdoğdu, İbrahim (2014) "17. Yüzyılın İkinci Yarısında Taşrada Yargı Uygulamaları: Harput Örneğinde Hakimü'ş Şer”, Frrat Üniversitesi Harput Araştırmaları Dergisi, Cilt: 1, Sayı: 2, s. 64.

42 BOA 3 Numaralı Mühimme Defteri, Hüküm No: 1409/a, s. 625.

43 Akman, s. 43; İpşirli, (2006) s. 312; BOA 5 Numaralı Mühimme Defteri, Hüküm No: 282, s. 209. Aynı naibin yirmi yıl süre ile görev yapmış olduğuna dair bir başka kayıt: BOA 5 Numaralı Mühimme Defteri, Hüküm No: 1481, s. 800.

44 Saydam, s. 300-301.

45 Naiblerin uzun süreli görev alması bazı hallerde uygun görülmüştür: “... Mektûb gönderüp; "Turşıcı Mîrzâ nâm kimesne otuz-krrk ylldan berü niyâbet idüp üç-dört def"a emrile ref" olmuş iken emre mugâyir niyâbet iderimiş; ahvâli görilüp arzoluna." diyü emrolunup mezbûr nâyib a yân-ı vilâyet huzûrında getürdilüp; "Ref'una emir vârid olmış mıdur?" diyü sü'al olundukda; "Emir gelmişdür." diyü halk yanında şüyû bulmağın ihtiyârrla ferâgat eyledüm idi; sonra istikâmetüm arzolunup niyâbet itmek içün ahkâm-ı şerîfe virilmiş idi. diyü cevâb idüp fi'l-vâk ' mezkûrun cemî' halk diyânetü istikâmetine şehâdet itdüklerin arzeylemişsin. Buyurdum ki: ... arzolunduğı gibiyse sâbıkâ virilen ahkâm-ı şerîfe mûcebince mezkûrı niyâbetden ref" itmeyüp emrüm mûcebince hıdmet-i niyâbete istihdâm eyleyesin. " BOA 12 Numaralı Mühimme Defteri I, Hüküm No: 570, s. 382. Burada otuz-kırk yıldan beri aynı yerde görev yapan naib görevden alınmak istenmiş fakat reayanın naibden memnuniyetini bildirmesi üzerine görevinde bırakılmıştır. 
girişimi ile görevden alınmıştır. Fakat naibden memnun olan halkın merkeze başvurusu üzerine padişah tarafından ilgili kadıya gönderilen belgede, naib atama yetkisinin kendisinde olduğu belirtilmiş fakat söz konusu naibin şeriatten ayrilmayan ve halka zulmetmeyen bir kimse olması halinde atanması emredilmiştir ${ }^{46}$. Bu bağlamda, merkezin bazı hallerde belirli kişilerin naib olarak atanması yönünde de kadıya emir vermiş olduğu görülmektedir. Merkezin naib atamalarına müdahale ettiği bu halde, adaletin tesisinin amaçlandığı ve Osmanlı Devleti'nin bu bakımdan naib atamalarında pragmatist davranmış olduğu değerlendirilebilir.

Bazı hallerde ise naib atanmasına dair belli yörelerden merkeze talep iletilmiştir: “... Dergâh-ı Mu'allâm’a mektûb gönderüp; ... kazâ-i mezbûrdan ba'zı kimesnelerün şerî̀ da'vâları olup görilmek içün ... Dubravenik beğleri kendü ra'iyyetlerine himâyet eyleyüp müslimânlara cüz'î bahâne ile veyâ deyn taleb itmekle metâ'larm ...cebr ile satun alup râzî olmayanları habsidüp ... diyü şikâyet olunup ...kıbel-i şer'den bir nâyib dahı oturmak lâzimdür ki, ... kuzât-ı sâbıka zamânlarında ... bir nâyib vaz' olmağıla haylî nef" müşâhede olmışdur; girü nâyib nasbolmasın murâd itdüklerin bildürmişsin... Arzolunduğı üzre bir nâyib ... gönderesin..." ${ }^{\prime 77}$ Buna göre Dubravenik bölgesinde Müslümanların taleplerinin gereği gibi karşılanmadığı, daha önce bölgede naib bulunduğu ve reayaya oldukça faydalı olduğu, yine bir naib atanmasının bölgedeki şer’i davaların görülmesinde fayda sağlayacağı bildirilmiş olup merkez tarafından Nova kadısına, söz konusu bölgeye şer’i davaları görmek üzere bir naib tayin etmesi emredilmiştir. Burada merkez kendisi bir naib belirlememiş, naib tayin etmesini kadıya emretmiştir. Dolayısıyla belirli kişilerin naiblik yapması hususunda devlet müdahalede bulunmamıştır. Ayrıca naib tayin edilmesindeki amaç, yöre halkının şer’i davalarının gereği gibi görülmesi talebinin karşılanması olduğundan, söz konusu emrin yine adaletin tesisini amaçladığı söylenebilir.

Son olarak Osmanlı Devleti'nde medrese mezunu olma şartı bulunan ulemadan infisal süresi içerisinde gelir sağlamak amacıyla naiblik yapanlar olmuş olduğu gibi medresede müderrislik görevini yürüten bir kişinin aynı

\footnotetext{
46 İnalcık, s. 77. Kadının görevden aldığı naibi tekrar göreve atamasının emredildiği bir başka örnek: BOA 5 Numaralı Mühimme Defteri, Hüküm No: 1431, s. 774-775.

47 BOA 7 Numaralı Mühimme Defteri I, Hüküm No: 1042, s. 517-518.
} 
zamanda naiblik görevini de üstlenmiş olduğu bilgisi kayıtlarda yer almaktadır. Örneğin, 1589 yllında Güle'de Hüsrev Beğ Medresesi'nde müderris olan Mevlana Salih, aynı zamanda İşbat kazasında naiblik görevini icra etmiştił ${ }^{48}$.

\section{NAİBİN GÖREVLERİ}

Osmanlı Devleti'nin adli teşkilatı içerisinde yer alan naiblerin çok çeşitli görev ve yetkileri olmuştur. Naiblerin, kadı yerine atanmış olmaları ile kadıların yanında görev yapmaları ise yetki ve görevlerinde farklılık oluşturmuştur. $\mathrm{Bu}$ bağlamda naiblerin görev ve yetkileri incelenirken, kadı yerine atanmış naibler ve kadının yanında görev yapan naibler olmak üzere iki başlık altında inceleme yapilacaktır.

\section{Kadı Yerine Atanan Naibler}

Kadı yerine atanmış naibler, kadıların sahip olduğu yetki ve görevlerin hepsine haiz olmuştur. Buna göre naibler bütün davaları görebilmiştir. Miras taksimi yapmış ${ }^{49}$, nikah kıymış, yetim ve kayıpların mallarını korumuştur. Vasi tayin ve azledebilmiş, vasiyet hükümlerine uyulmasını, vakıf senetlerine uygun hareket edilmesini denetlemiştir. Köle azadı, alacak davaları ve cinayet davalarını karara bağlamıştır ${ }^{50}$.

Aşağıdaki kayıt, naibin mahkemede hâkim statüsünde dava gördüğüne işaret etmektedir:

“...mezkur Pirinin, mezkur Haydar'ı mahkemeye ihzar ederek: "Sana iki çuval penbe bey' ettim akçamı taleb ederim” demesi, mezkur Haydar'dan sual olununca "görüb almadım" demesi, görüp aldığına mezkur Piri'den beyyine taleb olununca ityan-ı beyyineden aciz olup, mezkur Haydar'a yemin müteveccih olmasl, yeminden nükul edip, mahkeme nayibinin meblă̆-ı mezkuru mezkur Piri'ye hükmetmesi, ertesi gün mezkur Haydar’n "boğazımdan asıverin nayibin

48 Kılı̧, Cihan (2017) "XVII. Yüzyılın İkinci Yarısında Osmanlı İlmiye Teşkilatında İstihdam ve Hareket (Anadolu Kadıeskerliği Örneği)", (Yayımlanmamış Doktora Tezi), Yıldırım Beyazıt Üniversitesi Sosyal Bilimler Enstitüsü, s. 96; Beyazit, Yasemin (2009) "Osmanlı İlmiyye Tarîkinde İstihdam ve Hareket: Rumeli Kadıaskerliği Ruznâmçeleri Üzerine Bir Tahlil Denemesi (XVI. Yüzyll)", (Yayımlanmamış Doktora Tezi), Ankara Üniversitesi Sosyal Bilimler Enstitüsü, s. 251; Akiba, Jun (2005) "From Kadı to Naib: Reorganization of the Ottoman Sharia Judiciary in the Tanzimat Period", Frontiers of Ottoman Studies, ed. Colin Imber and Keiko Kiyotaki, vol. 1, s. 45.

49 Aköz, Alaaddin (2006) Kanuni Devrine Ait 939-941/1532-1535 Tarihli Larende (Karaman) Şer'iye Sicili, 2. Basım, Konya, Tablet Kitabevi, s. 42. 
hükmü kabul etmezem ve penbeyi dahi kabul etmezem" demesi. ${ }^{\text {"51 }}$ Naib, davac1 ve davalıyı dinlemiş, davacıdan iddiasını kanıtlamasını istemiştir. Davacının davalıya yemin teklif etmesi ve davalının yemin etmemesi üzerine davacı lehine hüküm vermiştir. Burada naibin davayı sonuçlandıracak hükmü vermiş olduğu "mahkeme nayibinin meblă̆-ı mezkuru mezkur Piri'ye hükmetmesi” ifadesinden açıkça anlaşılmaktadır. Ayrıca davalının hükme karşı çıkması kayda geçirilirken "naibin hükmü" ifadesi kullanılmıştır. Dolayısıyla kadı yerine atanan naibler, kadının yetkilerine sahip olmuş ve davaları mahkeme hâkimi statüsünde çözümlemiştir. Yine şeriye sicillerindeki kayıtlardan anlaşıldığı üzere kadı yerine atanan naibler, çözmüş oldukları uyuşmazlıkların taraflarına bu doğrultuda hüccet vermiştir. Örneğin "...Efendisi nayibi Habib Fakih hükm edip, elime hüccet-i şer'iye vermişdir...” şeklindeki şeriye kaydına göre boşanma kararına ilişkin hücceti naib düzenleyerek vermiştir ${ }^{52}$. Bu durum kadı yerine atanan naibin, şeriye mahkemesinin hâkimi sıfatıyla hareket ettiği bilgisini desteklemektedir.

Aşağıdaki örnek olayda ise kadı ve naib birlikte hareket etmiştir:

"Belviran'da ... Belviran Nayibi ve Aladă̆ Kadısı huzurunda Hacı Mustafa ... 21000 akça isbat edip...Karaman Beğlerbeğisi ... geldiklerinde mezbureyn kadı ve nayib ...paşa hazretlerine ... Mustafa'nın halin i'lam etdiklerinde ...939"53 Burada bahsi geçen Belviran ve Aladağ bölgelerinin her ikisinin de söz konusu tarihte kaza olmasi ${ }^{54}$ ve Aladağ kazasında kadı görevli iken Belviran kazasında naib görevli olması dikkat çekicidir. Bu durum Belviran kazasına kadı yerine naib atanmış olduğunu göstermektedir. Olaya baktığımızda ise Belviran'da, Belviran naibi ve Aladağ kadısı önünde alacağı olduğunu ispat eden davacının durumunu, kadı ve naib, Karaman Beylerbeyi'ne bildirmiştir. Yani aynı uyuşmazlığı kadıve naib birlikte dinlemiş ve beylerbeyine iletirken birlikte hareket etmiştir. Bu bağlamda naibin kadı yerine atandığ 1 durumlarda

51 Aköz, s. 69.

52 Bazna, Yalçın (2013) “1951/137 Numaralı (1810-1811 M. Tarihli) Trabzon Şer’iyye Sicili”, (Yayımlanmamış Yüksek Lisans Tezi), Fırat Üniversitesi Sosyal Bilimler Enstitüsü, s. 16; Aköz, s. 237-238. Naibin hüccet düzenlemesi ile ilgili bir başka örnek: “...mezkur İbrahim ise "mezkur Sefer asaleten 'an nefsühu ve vekaleten 'an kıbel-i ahihi Mehmed ve ‘an kıbel-i ahihi 'an nayib şer'an bana 20 akçaya bey' edip akçasın aldım deyü elime hüccet verdi” demesi, mezkur Sefer' in inkar etmesi, mezkur İbrahim'in hüccet-i şer'iye ibraz etmesi ile zikr olunan değirmenin dört sehiminin mezkur İbrahim'in mülkü olduğuna hükm olunması. Evail-i Zilka'de 940/14-23 Mayis 1534” Aköz, s. 255.

53 Aköz, s. 106.

54 Şafakcı, Hamit (2016) “Belviran Kazası Tekke ve Zaviyeleri (1476-1876)”, Vakıflar Dergisi, Sayı: 45, s. 6061; Aköz Alaaddin (1996) "XVI. Asrın İlk Yarısında Aladağ Kazası (1501-1540)”, Osmanlı Araştırmaları Dergisi, Sayı: 16, s. 68. 
"kadı" gibi hareket etmiş olduğu ve yargı teşkilatında kadının yardımcısı statüsünden ayrıldığg görülmektedir.

Yine görev almış oldukları yörede naibler; imam, zaviye mütevellisi gibi görevlilerin atanması yönünde merkeze arzda bulunabilmiştir. Örneğin, Haziran 1662 tarihli bir berata göre Harput Naibi Mevlana Mehmed’in arzı üzerine Zahiriye Zaviyesi’ne Molla Mehmed mütevelli olarak atanmış, Temmuz 1673 tarihli bir belgeye göre Harput Naibi Mevlana Mehmed'in arzı üzerine Ahi Musa Mescidi'ne bir imam atanmıştır ${ }^{55}$. Biraz yukarıda bahsetmiş olduğumuz üzere yerel yöneticiler, naib atanmasında rol oynayarak bu kurumun yozlaşmasına neden olmuştur. Burada vermiş olduğumuz örnekte ise naiblerin, yörenin belli bazı kamu görevlilerinin seçilmesinde rol oynadığı görülmektedir. Her ne kadar yerel yönetici gibi üst rütbede kişiler olmasa da yörede görev alacak bir imam veya zaviye yöneticisinin naib tarafından belirlenebilmiş olması önemlidir. Çünkü söz konusu görevliler yöre halkına etki edebilecek ve naiblerin, reaya üzerinde nüfusunu arttırmasında rol oynayabilecek konumdadırlar.

Son olarak kadı yerine atanmış olan naibler, adli işlerin dışında ürün ve hizmet narhlarının belirlenmesi, merkeze asker ve zahire ${ }^{56}$ tedarik edilmesi, avarız akçesinin toplanması, merkezden gönderilen emir ve fermanların halka duyurularak sicile işlenmesi gibi idari görevlere de sahip olmuştur ${ }^{57}$.

Görev yaptıkları mahkemeler bakımından naibler; bab naibleri, mevali naibleri, arpalık naibleri gibi çeşitli şekillerde isimlendirilmiş olup söz konusu naiblere farklı başlıklar altında aşağıda yer verilmiştir.

a. Bab Naibleri

Osmanlı Devleti’nin büyük şehirlerinde bab mahkemeleri adıyla görev yapan mahkemeler bulunmakta olup söz konusu mahkemelere, kadıların yardımcısı sıfatıyla naibler başkanlık etmiştir. Kuruldukları ilk tarih kesin olarak bilinmeyen bab mahkemeleri, Osmanlı’nın İstanbul, Kahire, Şam, Selanik, Bağdat gibi büyük şehirlerinde yer almıştır. Bunlar arasında en önemlisi İstanbul bab mahkemesi olmuştur. İstanbul bab mahkemesine başkanlık eden naib, İstanbul kadısına vekaleten dava dinlemiş, uyuşmazlıkları karara bağlamıştır. Bab naibleri yargılama işlerini yürütürken baş katip, katipler ve vekayi katibi gibi yardımcılara sahip ol-

Erdoğdu, s. 63.

56 Zahire, gerekli hallerde harcanmak üzere anbarlarda saklanan hububat ve yiyecek anlamına gelmektedir. Devellioğlu, s. 1358.

57 Demir, s. 45. 
muştur. Kaynaklarda özellikle 17. yüzyılda sıkça geçen bab mahkemeleri, II. Meşrutiyet sonrasında mahkemelerin birleştirilmesine kadar varlığını sürdürmüştür ${ }^{58}$.

Bab mahkemelerinin başkanlığını yürüten bab naibleri dışında, kadının yanında görev yapan bab naibleri de Osmanlı Devleti’nde mevcut olmuştur. Kaza veya mevali kadılıklarında kadının yardımcısı statüsünde olan bab naibleri, kadının iş yoğunluğu sebebiyle gerektiğinde vekaleten dava dinlenmiştir ${ }^{59}$. Örneğin 19. yüzyıl şeriye sicillerine göre Diyarbakır kadılığında genellikle baş katipler bab naibi olarak tayin edilmiş, yine 28 Kasım 1803 tarihli bir hüccete göre nahiye kadılı̆̆ yapan bir kimse aynı zamanda Diyarbakır kadılığında bab naibi sıfatıyla görev almıştır ${ }^{60}$. Belirtmek gerekir ki burada bahsi geçen bab naibleri kadı yerine atanmamış, kadı yanında görev yapmıştır.

b. Mevali Naibleri

Osmanlı Devleti’nde kadılıklar dereceleri bakımından ikiye ayrılmıştır. Bunlardan daha yüksek dereceli olan mevleviyet kadılıkları olup diğeri ise kaza kadılıklarıdır. İstanbul, Edirne, Bursa gibi payitaht şehirlerinin yanı sıra kültür ve nüfus bakımından öne çıkan şehirler de stratejik öneme sahip olmaları sebebiyle mevleviyet kadılığı olarak sınıflandırılmıştır. Söz konusu kadılıklar, önemli konumları gereği yönetim ve adli işleri bakımından da önemsenmiş ve buralara tecrübeli ulemadan kadılar atanmıştır. Mevleviyet kadılığına atanan kadılar, mevleviyet rütbesini kazanmış olup bu kişiler hakkında "mevali” ifadesi de kullanılmiştır ${ }^{61}$.

İşte mevleviyet derecesindeki kadılıklardan İzmir, Diyarbakır, Ankara, Konya, Kayseri, Sivas gibi Anadolu'daki bazı şehirlerin kadılıklarında 18. yüzyıl sonlarında, naiblerin görev yapmış olduğu belirtilmektedir. Örneğin Mevleviyet derecesindeki Bursa’nın naibliği verilen kadı Ahmet Nazif Efendi İznik’te kadılık yaptığından yerine başkasını naib olarak atamıştır ${ }^{62}$.

\footnotetext{
58 İpşirli, Mehmet (1991) İslam Ansiklopedisi, "Bab Mahkemesi”, Türkiye Diyanet Vakfı İslam Araştırmaları Merkezi, Cilt: 4, s. 362.

59 Uzunçarşill, s. 121.

60 Yılmazçelik, İbrahim (2012) "XIX. Yüzyılda Osmanlı Taşra Teşkilatının Önemli Merkezlerinden Biri Olan Diyarbakır'da Bazı Görevlilerle İlgili Tespitler", Ankara Üniversitesi Osmanlı Tarihi Araştırma ve Uygulama Merkezi Dergisi, Sayi: 31, s. 236.

61 Unan, Fahri (2004) İslam Ansiklopedisi, "Mevleviyet", Türkiye Diyanet Vakfi İslam Araştırmaları Merkezi, Cilt: 29, s. 467.

62 Çadırcı (1991) s. 84-85.
} 


\section{c. Arpalık Naibleri}

Osmanlı Devleti'nde Anadolu şehirlerinin pek çoğu, ulemalara veya görevinden azledilen kazaskerlere "arpalı"" olarak verilmiştir. Bu kişiler ya kendi naiblerini bölgeye göndermiş ya da o bölgeden belirledikleri bir kişiyi yerlerine naib olarak atamışlardır. Bu şekilde atanan arpalık naibleri, bölgenin adli işlerini yürütmüştür. Örneğin, eski şeyhülislamlardan Yasincizade Esseyid Abdülvehhab Efendi, kendisine arpalık olarak verilen Ankara kazasının adli işlerini görmek üzere, İbrahim Efendi isimli bir naib atamış, 1833’te ise söz konusu kaza Anadolu kazaskeri Abdülkadir Bey’e arpalık olarak verilmiş ve kendisi naibi olan Mehmed Nafi Efendi'yi bu işle görevlendirmiştir ${ }^{64}$.

Emekliye ayrılmış kadılara da Osmanlı Devleti tarafından arpalık tahsis edilmiştir. Kadılar bu arpalıklara naibler tayin etmiş, söz konusu naibler, almış oldukları harçlardan bir kısmını kadılara vermiş diğer kısmı ile geçinmiştir. $\mathrm{Bu}$ durum, naiblerin daha fazla kazanç sağlamak amacıyla görevlerini suiistimal etmelerine yol açmıştır ${ }^{65}$.

Görevinden azledilen veya emekliye ayrılanlar dışında hali hazırda belli bir görevi yürütmekte olan ulemaya da arpalık tahsis edilmiştir. Örneğin, 1665 yılında Kudüs payesi ile Karaferye'de müftü olan Ebubekir'e arpalık olarak Karadağ ve Eğribucak kadılıklarının verilmiş olması dikkat çekici bir örnektir. Üst düzey ulemadan olan müftü Ebubekir, aynı zamanda iki kazanın kadılı̆̆ını da yürüttügü için Karadağ ve Eğribucak kadılıklarına naib atamıştır ${ }^{66}$. Buna göre devlet, hali hazırda müftülük görevini yürüten bir kişiye arpalık tahsis ederek, kişinin söz konusu arpalıklara vekil atayacağını zımnen kabul etmiştir. Hatta iki farklı bölgenin arpalık olarak tahsis edilmesi, kişinin yürütmekte olduğu bir görevi olmasa dahi en azından birine vekil atayacağını göstermektedir. Bu anlamda, arpalıklara

63 Mevleviyet derecesindeki ulemanın görev alabileceği yeterli sayıda yüksek memuriyet bulunmadığından bu kişilere ek gelir niteliğinde daha alt derecedeki kaza kadılıkları verilmiştir. Bu kişilerin onurlarını okşamak maksadıyla "atının arpasına karşılık" olarak bu yerlerin gelirlerinin verildiğinden yola çıkılarak söz konusu kazalara arpalık denilmiştir. Feyzioğlu, Hamiyet Sezer/Kılıç, Selda (2005) "Tanzimat Arifesinde KadılıkNaiplik Kurumu", Tarih Araştırmaları Dergisi, Cilt: 24, Sayı: 38, s. 34.

64 Çadırcı (1991) s. 85. Ulema kendisine verilmiş arpalık için daha çok naib göndermiş olsa da kendi arzusu ile arpalığına giden de olmuştur. Bazı arpalık sahipleri ise cezalandırılma amacıyla arpalığına kadılık yapmak üzere gönderilmiştir. Örneğin, Damat Ali Paşa'nın Avusturya seferine itiraz eden eski kazaskerlerden Mirzazade Şeyh Mehmed Efendi, Bulgaristan’daki arpalığına gönderilmiştir. Uzunçarşılı, s. 123.

65 Aydın, (1994) s. 399.

66 Alan, Ercan (2013) "Kadıasker Ruznamçe Defterlerine Göre XVII. Yüzyılda Rumeli'de Kaza Teşkilatı ve Kadılar”, Güney-Doğu Avrupa Araştırmaları Dergisi, Sayı:23, s. 68. 
naib atanmasının önü devlet tarafından da açılmış olup bu durum adalet sistemine kaçınılmaz olarak olumsuz etkide bulunmuştur.

\section{Kadı Yardımcısı Olan Naibler}

Naib, Osmanlı adli teşkilatı içerisinde esas olarak kadı yardımcısı sıfatıyla görev almıştır. Kadıların yanında yardımcı sıfatıyla görev yapan naiblerin de adli görevlerinin yanında idari görevleri de bulunmuştur.

a. Adli Görevleri

Kadı yanında görev alan naiblerin adli görevlerinden en önemlisi davayı bizzat görmesidir. Gerçekten de kadı, yanında görevlendirmiş olduğu naibe, dava görme yetkisi vermiş ise söz konusu naib, kadı gibi hukuki uyuşmazlıkları karara bağlayabilmiştir ${ }^{67}$. Bu yöntem çerçevesinde özellikle farklı mezheplerden insanların yoğun bulunduğu bölgelerde şeriye mahkemelerine her bir mezhepten ayrı ayrı naibler atanmıştır. Örneğin Mekke kadılığında Şafi, Maliki ve Hanbeli mezheplerine mensup naiblerin görev yaptığ 1 kayıtlarda geçmektedir ${ }^{68}$. Bununla birlikte söz konusu kayıtta naiblerin önemli hususlarda karar alırken kadıyla birlikte hareket etmeleri, kadıya danışmadan karar almamaları emredilmiş; böylece şeriata aykırı karar verilmesi ihtimalinin önüne geçilmesi amaçlanmıştır.

Dava görme yetkisine haiz olmayan naibler ise sorgu hâkimi şeklinde davacı, davalı ve şahitleri dinlemiş, şahitler hakkında güvenilirlik soruşturması yapmıştır. Bu şekilde naibin sorguladığ şahitleri, kadı da tekrar dinleyerek hüküm vermiştir ${ }^{69}$.

Naibler, kadı tarafından keşif yapması amacıyla da görevlendirilmiştir. Örneğin şeriye sicillerindeki kayıtlara göre Harput yöresinde mahkeme tarafindan, sadat-1 kiramdan kimseler ile reaya arasında çıkan toprak uyuşmazlı̆̆ını yerinde görerek çözmesi için Mevlâna İsmail adlı bir naib görevlendirilmiştir. Burada Harput kadısı; naibini, gittiği yerdeki uyuşmazlığı çözmesi için de yetkilendirmiştir. Aynı mahkemeden bir diğer örnekte ise Harput'a bağlı Uluabat Nahiyesi Haringid Çayı'nda bir kişinin boğulduğu olayın yerinde keşfi için naib Mevlâna esSeyyid Hacı Ömer Efendi görevlendirilmiştir. Kasım 1672 tarihli hüccete göre ise dirlik sahipleri ile bazı köylüler arasında çıan sınır anlaşmazlığının çözümlenmesi için mahkemeden naib istenmiş olup Mevlâna Muhammed Efendi keşif yap-

Demir, s. 45; Bayındır, s. 43.

BOA 5 Numaralı Mühimme Defteri, Hüküm No: 211, s. 167-168.

Demir, s. 45; Bayındır, s. 43. 
ması için atanmıştır ${ }^{70}$. Bir başka kayıtta ise fahişe ile içki içenlerin tespit edilmesi için subaşı tarafından naib görevlendirilmesi talep edilmiştir ${ }^{71}$. Bu da göstermektedir ki şeriye mahkemesi tarafından keşif için naib görevlendirilmesi, yalnızca mahkemenin iradesi ile değil reayanın veya kamu görevlilerinin talebi üzerine de mümkün olmuştur.

Miras paylaştırmada bağ, bahçe veya arazi gibi mallar söz konusu olduğunda naibler atanmış ve ilgili malları yerinde görmek üzere keşfe çıkmıştır. Konya kadı sicillerindeki miras davaları kayıtlarında geçen "...canib-i şer'den Ahmed na'ib ta'yin olunup müteveffa-yı merkumun mahalle-i merkumede vaki' menzili üzerine zeyl-i kitabda ismleri mestur olan müslimin ile varup nazar olundukda...", “...canib-i şer'den na'ib ta'yin olunan Ebuss'ud Efendi ile bă̆-ı mezburun üzerine varup..." ${ }^{\prime 2}$ ifadeleri bu hususa açıkça işaret etmektedir.

Yine naibin keşfe çıkması ile ilgili bir başka örneğe aşağıda yer verilmiştir:

“...bağım evinin kapısı önünde, evimin duvarında, yolumda ... Mustafa bir kerevid vaz' edip ... sabıkan kadı ... zemanında mezkur Mustafa ile niza' edip mevlana-yı mezkur zikr olan kerevidin üzerine nayibi olan Muslihiddin'i irsal edip ... Mustafa vaz' ettiği kerevidin bana zararı vardı̆̆ın isbat edip nayib-i mezkur kal'ına hükm edip hükmünü mevlana-yı mezkura 'arz ettiğinde hükmü mukarrer tutup ol dahi niza' olunan kerevidin kal'na hükm etti..." ${ }^{\prime 3}$ Burada uyuşmazlık konusunu yerinde incelemekle görevlendirilen naib, şikayet konusu yapının kaldırılmasına hükmederek hükmünü kadıya bildirmiştir, kadı da aynı şekilde karar vermiştir. Buna göre keşif için görevlendirilen naib tarafından verilen karar, her zaman son karar olmamış; kadı tarafından da denetlenmiş olup son karar kadı tarafından verilmiştir. Bu da kadının yanında dava bakmakla yetkilendirilen naiblerce verilen hükümlerin, daha iyi eğitim almış olan kadılar tarafından da denetlenmiş olduğunu göstermektedir. Bu durum adaletin tesisine önem verildiğine işaret etmektedir.

İstanbul kadılıklarının bazılarında, gece vakti dahi yargılama görevi sürdürülmüş olup bu işi yürüten görevliye "gece naibi” denilmiştir. Gece naibi, akşamdan

Erdoğdu, s. 64, 73, 78-79.

“... subaşı ... mahkeme-i şerifeye adem gönderüp...fahişe ile ma'a oturup şurb-ı hamr ve fisk eyledikleri mesmu' um olmuşdur üzerine varılup tahrir olunmast içün taraf-ı şer'den na 'ib taleb iderin didikde..." Orak, Muhammet Ali (Editör) (2014) Konya Kadı Sicili (1070-1071/1659-1661) Defter 14, Konya, Konya Büyükşehir Belediyesi Kültür Yayınları, s. 254-255.

Orak, Defter 10, s. $72,74$.

Aköz, s. 218. 
sabaha kadar görevinin başında bulunmuş ve acele görülmesi gereken adli işleri yürütmüştür ${ }^{74}$. Aşağıda gece naibi ile ilgili bir şeriye sicili kaydına yer verilmiştir:

"Mahmiyye-i Galata subaşısı adamlarından ... Mustafa ... gelüb ... bazı namahrem kimesneler ... fahişe avret ile şürb-i hamr iderler kıbel-i şer'den üzerlerine varlub ahz olunmalarm taleb iderim didükde gice naibi olan Yunus irsal olunub...varub keşf eyledikde ..."

Gece naibi uygulamasına İstanbul kadılıklarında rastlanmış olmakla birlikte Osmanlı Devleti'nin başka bazı bölgelerinde de gece vakti mahkemelerin açık olduğu bilinmektedir. Şeriye sicillerindeki bir örneğe göre Harput yöresinde gece vakti içki içip elinde kılıç ile bir hanımın evinin önünde bağıran Bekir bin Musa isimli kişi yakalanmış ve "gece ile mahkeme-i şer’e ihzar" edilmiştir. Söz konusu kayitta, Harput mahkemesinde gece vakti hangi görevlinin bulunduğu ise tespit edilememiştir $^{76} .19$. yüzyılda Diyarbakır'ı inceleyen bir çalışmada ise sicil kayıtlarına göre Diyarbakır kadılı̆̆ında gece vakti bab naibinin görev yapmış olduğu belirtilmiştir ${ }^{77}$. Bu durum bab naibi ile gece naibi sıfatlarının aynı kişide birleşebilmiş olduğunu göstermektedir.

Naibler, merkez tarafindan teftiş ile görevlendirilen kadıyla birlikte teftiş yapabilmiştir. Kayitlarda geçen müessir fiile ilişkin bir olayda “...teftiş idüp göresin deyu ferman olunmağın ... kadı ... naibleri ile teftişe şüru olunup ..." ${ }^{\text {"8 }}$ ifadeleri söz konusu kadının teftiş için görevlendirilmiş olduğu olayda birden fazla naibin yardımından faydalandığına işaret etmektedir. Bu bağlamda naibler adli hususlardaki teftişlerde de görev almıştır.

Son olarak kazalara atanan kadılar, kaza merkezine tabi olan nahiyelere adli işleri yürütmesi amacıyla naibler atayabilmiştir. Osmanlı Devleti’nin nahiye ve köyler dışındaki diğer idari birimleri aynı zamanda yargı merkezi niteliği taşımış olup her yargı merkezinde bir kadı bulunmuş ve o bölgenin hâkimi ve beledi işlerini yürüten bir mülki amir olmuştur. İş yükü çok fazla olan söz konusu kadılar, adli işleri yürütmeleri için nahiyelere naibler atamıştır. Kadılar tarafından nahiye-

\footnotetext{
74 Akdağ, Mustafa (2018) Türkiye’nin İktisadi ve İçtimai Tarihi (1453-1559), 4. Baskı, İstanbul, Yapı Kredi Yayınları, s. 427; Avcı, Mustafa (2012) Türk Hukuk Tarihi Dersleri, 1. Baskı, Konya, Mimoza Yayınları, s. 107.

Akman, s. 44-45.

Erdoğdu, s. 67.

Yılmazçelik, s. 235.

BOA 5 Numaralı Mühimme Defteri, Hüküm No: 1355, s. 741-742.
} 
lere atanan naiblere, kaza naibi denilmiştii ${ }^{79}$. Örneğin İstanbul'da, bilad-1 selase denilen Üsküdar, Galata, Eyüp ve İstanbul kadılı̆̆ı görev yapmış olup söz konusu kadılıkların yanında Tophane, Beşiktaş, Balat ve Adalar gibi kaza naiblikleri bulunmuştur ${ }^{80}$. Kaza naibi, atanmış olduğu nahiyenin şeri işlerini, kaza kadısı adına yürütmüştür. Yine naibler, kadı tarafından şer’i işler için köylere gönderilebilmiş olup bu şekilde kadılar, uzak yörelerde meydana gelen olaylar hakkında bilgi edinebilmiştir. Naibler, kadının yanında kalıp gerektiğinde kadıya vekalet edebilmiş, aynı zamanda kazalarda bab naibliğini de kaza naibleri yürütmüştür ${ }^{81}$. Burada da kaza naibi ile bab naibi sıfatlarının aynı kişide birleşebilmiş olduğu görülmektedir.

b. İdari Görevleri

Kadı yanında görev yapan naibler, kadıya çeşitli idari görevlerinde yardımc1 olmuştur. Özellikle İstanbul kadısının iş yükünün fazla ve çeşitli olması ve tek başına bu iş yükünün altından kalkmasının güç olması sebebiyle, çok sayıda yardımcısı bulunmuştur. Bunlar arasında çeşitli sıfatlarla anılan naibler de mevcuttur. Söz konusu naiblerden kimisi mahkemede kadının yanında olmuş, kimisi İstanbul'un belirli bölgelerinde kadiya vekaleten bulunmuştur ${ }^{82}$.

İstanbul dahilindeki ticari işleri, esnafi, fırınları ve şehre girip çıkan eşyayı kontrol etmekle kadı naibleri görevlendirilmiştir. Örneğin, İstanbul'da çarşı ve pazarları dolaşarak esnafın alışverişini, terazilerini teftiş eden ayak naibleri, esnafin arasındaki ihtilafları çözümlemiştir. Ayak naibleri, sahtekarlık veya vurgunculuk yapan esnafı cezalandırmış, ayrıca kanuna ve şeri hükümlere aykırı davranan esnafı da men ile cezalandırabilmiştir. Şüpheli mahallere, memnu mahallere ve gizli şekilde içki içilen yerlere baskın yapmak da ayak naibinin görevi olmuştur. Bunun dişında çardak naibi fiyatları tayin ve kontrolle görevli olup bu konudaki uyuşmazlıkları çözümlemiştir. Çardak naibi, Çardak iskelesi denilen bölgede oturmuş ve deniz yolu ile hariçten gelen bütün eşyayı kontrol ederek resmini almıştır. Çardak naibine yardım eden yeniçeriler olduğu gibi maiyyetinde "pazar gammazları” denilen çok sayıda görevli bulunmuştur. Mum naibi mumculuk yapan esnafin işlerine bakmakla görevli iken yağ naibi yağ işleriyle uğraşmıştır. İstanbul Yağkapanı'nda bulunan yağ naibi, sade yağ ve zeytinyağı ile ilgili işlerle

79 Cin/Akgündüz, s. 275. Kadılar tarafından başka kadıların yetkisinde olan kazalara naib gönderilmek suretiyle müdahale edilen durumlar da yaşanmıştır. Örneğin; Orak, Defter 10, s. 10-11. 
ilgilenmiş olup esnafin ve tüccarların arasındaki uyuşmazlıkları çözümlemiştir. Unkapanı'nda bulunan kapan naibi, zahire ve ekmekçileri denetlemiş, İstanbul'un ihtiyacını giderecek yeterlilikte ve türde zahirenin teminini ve kontrolünü sağlamıştır. Ayrıca ekmekçilerin hesaplarını incelemiş, davalar çözümlemiştir. Kapan naibinin maiyetinde bir de veznedar bulunmuştur. Avarız naibi ise avarız vergisini toplamakla görevli olmuş, vergi vermeyenler aleyhinde hüküm vermiştir. Son olarak pastırma naibi, İstanbul'un ihtiyacını karşılayacak kadar pastırmalık hayvanın alınıp satılmasını denetlemiş, pastırma fiyatlarını tespit etmiş ve bu konuda çıkan ihtilafları çözümlemiştir ${ }^{83}$. Burada naiblerin idari görev alanlarıyla ilgili uyuşmazlıkları çözmekle de yetkili oldukları görülmektedir. Bu anlamda belli alanda uzmanlaşmış olan naiblerin o konudaki ihtilafları da en doğru şekilde çözümleyecek kişi olarak görüldüğü dikkat çekmektedir.

Aşağıda yer verdiğimiz örnekte naiblerin cizye vergisini toplamakla görevlendirilebilmiş olduğu anlaşılmaktadır:

“...Istanbul Mahkemeleri Naibleri, ... Rum, Ermeni, Trabzon'daki gayr müslimler ... cizyelerini, ... toplamak, tahsil etmek ve hazineye yollanmak hususunda, ... yazll emir varit olmuştur. Şimdi siz, kendinize bağh olan yargı çevresinde bulunan reayadan ... cizyeleri tahsil edesiniz..." ${ }^{\prime 4}$

Söz konusu kayıt aynı zamanda, naiblerin, üstlenmiş oldukları görevlerle ilgili idare tarafından bizzat muhatap alındığına da işaret etmektedir. Anadolu'nun farklı bölgelerinde naibler ile yapılan yazışmalara rastlanılmıştır. Aşağıda vereceğimiz örnekte ise kadıya verilen emir yerine getirilmemiş ve naib tarafından merkeze gönderilen mektupta kadı olmaması sebebiyle emrin icrasının yetişmeyeceği bildirilmiştir. Merkez ise söz konusu hususun önemli olduğunu ve bu işle naibin bizzat ilgilenmesini emretmiştir. Dolayısıyla kadının yapması gereken idari işler hakkında gerekli görüldüğünde naibler de görevlendirilebilmiştir:

"Erim Nâibine hüküm ki: Mektûb gönderüp ... Sımâv kadısına virilüp ...dört aydan ziyâde olup gelmeyüp mesâlih-i müslìmîn ve mühimmât-ı mîrî mu'attal olup husûsan kendir emri hâlî kalup kadı olmaynca sefere irişmez deyü bildirmişsin... buyurdum ki; ... kendir umûrnna sen bi'z-zât mukayyed olup ...

İpşirli (2006) s. 312; Demir, s. 45; Uzunçarşıll, s. 145-146.

Şer'iye Sicilleri II, s. 165. 
üzerine durup irişdürüp bu cânibe gelen gemilere tahmil idüp göndermek bâbında ikdâm ü ihtimâmm zuhûra getüresin... ${ }^{\text {\$5 }}$

Merkez tarafindan kadıya verilen adli ve idari görevlerin bir arada yürütülememesi halinde naibin idari görevle ilgilenmesi emredilmiştir: "Gelibolı kâdîsına hüküm ki: ... "Bundan akdem Biga sancağı beğin teftîş içün sana hükm-i şerîfüm gönderilüp... kürekci ihrâcı içün emr-i şerîfüm ...; "Teftîşe mâni" olmışdur." diyü bildürmişsin... kürekci husûsın nâyibün ile gördürüp... sen emr-i sâbıkum mûcebince ... teftîş husûsına mübâş̧eret üzre olasın. ${ }^{\text {'86 }}$ Burada Gelibolu kadısı, merkeze kürekçi gönderilmesi görevinin, Biga Sancağı Beyi’ni teftiş etmesine engel olduğunu bildirmiş olup merkezden gelen cevapta, kürekçi tahsisi işiyle naibin ilgilenmesi, kadının ise teftiş işini yürütmesi emredilmiştir. Söz konusu olayda adli işin değil idari işin naibe verilmesi dikkat çekicidir. Zira kadı ve naibin almış olduğu medrese eğitimi arasındaki fark fazladır. Bu bakımdan naibin idari işle görevlendirilmiş olması, adli işin daha önemli görüldügüne ve kadı tarafından çözümlenmesine önem verildiğine işaret etmektedir.

Kadı tarafından merkeze gönderilen bir kayıtta ise emredilen kerestelerin hazırlanması hususunda naibi Muslihiddin'in "ehl-i vukuf"s7 olduğu belirtilmiş olup merkez tarafından verilen cevapta, gemi mühimmatı için adı geçen naibin görevlendirilebileceği bildirilmiştir ${ }^{88}$. Buna göre devletin gemilerinde kullanılacak malzemelerin tedarik edilmesi hususunda da naibler rol alabilmiştir. Bir başka kayıtta ise naibin köprü yapımında görevlendirilmesi söz konusudur ${ }^{89}$. Bu şekilde çok farklı alanlarda görev alan naiblere rastlanmıştır.

Naibler, yanında görev yapmış olduğu kadının, merkez ile iletişim kurmasında da rol oynamıştır. Mühimme defterlerinde geçen "...Gölbazarı kadısınun na'ibi Kemal ile Südde-i sa'adet'üme mektub gönderüp... "90 ya da "Rodoscuk kadlsına hüküm ... Naibin mektub gönderup... ${ }^{\text {x1 }}$ şeklindeki kayıtlardan anlaşıldığ 1 üzere kadılar naibleri aracılığıyla Divan-1 Hümayun'a mektup göndermiş ve devlet merkezi ile haberleşmesinde naiblerden faydalanabilmiştir ${ }^{92}$. Yine İstanbul'da

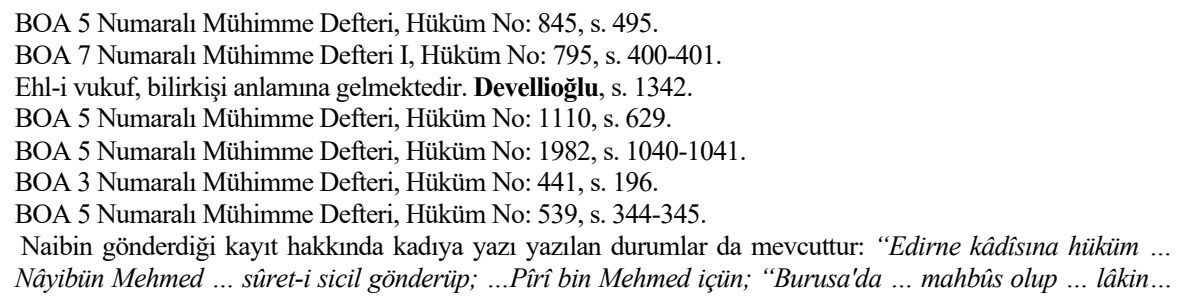


yaşanan et sıkıntısını gidermek amacıyla belli bölgelerden koyun talep edilmiş olup kadılara yazllan emirde “...koyunların ... ihrac itdürüp na’ibleriniz koşup ... gönderüp ... koyun eminine teslim itdiresin. ${ }^{\text {,93 }}$ şeklinde naiblerin bu görevi yerine getirmesi emredilmiştir. Dolayısıyla naibler, görev yapmış oldukları bölgenin merkez ile alışverişinde de rol almıştır.

\section{NAİBLİK ÜCRETİ}

Osmanlı Devleti’nde naiblerin ücreti, işlemler karşılığında alınan harçlardan karşılanmıştır. Bu uygulama kadılar için de geçerli olduğundan, burada kadıların ücretlerinin nasıl belirlendiğinden bahsetmek gerekmektedir. Osmanlı Devleti'nde önceleri kadıların belirli bir maaşı olmamıştır. Kadılar, icra etmiş oldukları işlemlere karşılık alınan harçların bir kısmı ile geçinmişlerdir $^{94}$. Bu miktarı az bulan veya geçinemeyen bazı kadılar ise haksız kazanç sağlamak amacıyla usulsüz işlemlere başvurmuştur. Yıldırım Beyazıt'ın yolsuzluk yapan kadıları önce bir eve koyarak yakmak istediği; vezirinin, bu durumun kadıların geçinecek kadar maaşlarının olmamasından kaynaklandığını söylemesi ve ülkede kadı kalmayacağının bildirilmesi üzerine vaz geçtiği ve kadıların görmüş olduğu işler için belirli bir ücret tespit ettiği bilinmektedir ${ }^{95}$.

Osmanlı Devleti, kadı ve naiblerin hangi işlemlerden ne kadar ücret alacağını kanunnameler ile düzenlemiştir. Alınan ücretler, icra edilen işleme veya bakılan davaya göre nikah, ıtak, talak, sicil, hüccet, mürasele gibi isimlerle anılmıştır ${ }^{96}$. Bu hususu özel olarak düzenleyen bir kanunname hükmü:

“...Ve ıtık-name'den altmışaltı akçe; ellisi kadının, onu naibin .... Ve müraseleden onaltı akçe ve sicillata sebt olunan kazayadan resm-i sicil sekiz akçe;

dört-beş nefer eyülüğine şehâdet eyledüklerin” bildürmiş. ... Nâyib ol vechile sicill eylemeğe sebeb nedür? ...teftî̧s eyleyüp göresin; sâbıkâ sirka töhmeti sâbit olup sicill olmış iken hâlâ nâyib-i mezbûr ol vechile sicill eylemeğe sebeb nedür, fi'l-vâki ' günâhı olmayup hılâf-l vâkl ' mı habsolmışdur, yohsa hırsuzluğı mukarrer iken nâyib-i mezbûr hılâf-ı vâkı ' mı sicill eylemişdür, ...yazup bildüresin.” BOA 12 Numaralı Mühimme Defteri I, Hüküm No: 692, s. 445.

93 BOA 5 Numaralı Mühimme Defteri, Hüküm No: 159, s. 134.

94 Uzunçarşılı, s. 91; Halaçoğlu, 127.

95 Uzunçarşılı, s. 91-92; Kılınç, Ahmet (2016) "Yıldırım Bayezid Han’ın Devlet Yönetimine Işık Tutan İki Osmanlıca Makale ve Tahlilleri”, Yıldırım Beyazıt Hukuk Dergisi, Sayı: 1, s. 10-11. Vakıa için ayrıca bakınız: Aşık Paşazade (2003) Osmanoğulları'nın Tarihi, Hazırlayanlar: Yavuz, Kemal/Saraç, Yekta, İstanbul, K Kitaplığı Yayınları, s. 39-40.

96 İpşirli (2006) s. 313. 
altısı kadının, biri naibin ... Ve müteveffa muhallefatı kısmet olundukda binde onbeşakçe alınup; onu kadının, beşi naible eminindir... ${ }^{\text {ग97 }}$

Yine 1480 tarihli bir kanunnameye göre ıtakname düzenlendiğinde kadı 30 akçe alırken naib 1 akçe, nikah kıyıldığında kadı 20 akçe alırken naib 5 akçe, hüccet düzenlendiğinde kadı 15 akçe alırken naib 1 akçe almıştır. 1644 tarihli başka bir kanunnamede ise itakname düzenlendiğinde kad1 50 akçe alırken naib 10 akçe, nikah kıyıldığında kadı 20 akçe alırken naib 5 akçe, hüccet düzenlendiğinde kadı 20 akçe alırken naib 5 akçe almıştır ${ }^{98}$. Görüldüğü üzere zaman içerisinde bazı işlemlere ait ücretler sabit kalırken bazıları değişmiş olup kadı ve naib arasındaki ücret farkı ya sabit kalmış ya da açılmıştır.

Kanunnamelerde ücreti kadı ile paylaşıma tâbi tutulan naib, kadının yardımcısı statüsünde olan naibdir. Kadı yerine atanan naibler ise kadı için belirlenmiş olan ücretleri kendi nam ve hesaplarına tahsil etmiştir. Ayrıca 16. yüzyıl sonlarına doğru kanunlarla belirlenen kadı ve naib ücretleri, 19. yüzyıla kadar değişmeden uygulanmıştır ${ }^{99}$.

\section{E. NAİBİN VE HÜKÜMLERİNINN DENETLENMESİ}

Osmanlı Devleti, naibleri hakkında merkeze yapılan şikayetleri titizlikle incelemiştir. Aşağıda yer vermiş olduğumuz kayıtta suç işleyen kimseleri koruyan naibler olduğundan bahsedilmektedir:

"Menteşe Beyine hüküm ... Mektûb gönderüp ... ehl-i fesâd suhteler ... müslimanların evlerin basup mâlların alup ekser fesâd idenlerin karındaşları ... ba'zı nâyib ... anlara mu'âvenet olup ele virmezler ... Anun gibi ... suhte tâ'ifesinden fesâd ü şenâ'at idenleri ele getürüp ... da'vâa-yı hakk idenler ile berâber idüp toprak kadıların ahvâllerin şerle görüp ... lâzım geleni icrâ idüp ... kısâs lâzım gelmeyenleri ... küreğe koşup sâbit olan fesâd ü şenâ'atlarm sûret-i sicillerin ... gönderesin. Anun gibi mu'ayyen ve zahîr olanların dahi ehl-

\footnotetext{
97 Akgündüz, Ahmed (1990) Osmanlı Kanunnameleri ve Hukuki Tahlilleri, I. Kitap, İstanbul, Fey Vakfı Yayınları, s. 191.

98 İnalcık, s. 78.

99 Demir, s. 45.
} 
i fesâd ü şenâ'ate mu'ayyen ü zahîr oldukları sâbit olanların sûret-i sicillerin ... gönderüp ... anlar hakkında emrim ne vechile olursa amel eyleyesin..."100

Söz konusu kayıtta Menteşe Beyi, suç işleyen kimselere yardım eden ve koruyan köy kethüdası, naib ve hatip gibi görevlilerin olduğunu merkeze bildirmiş olup merkez ise suçlulara yardım ettiği sabit olan bu görevliler hakkında bilgilerin gönderilmesini ve bu konuda vereceği emre göre hareket edilmesini bildirmiştir. Dolayısıyla suç işlediği konusunda hakkında şikâyet olan naibler ile ilgili kararlar merkez tarafından alınabilmiştir. Bir başka örnekte ise hakkında sahte mühür yapmak, aldatıcı hüccetler düzenlemek ve halkı dolandırmak gibi suçlamalar bulunan naib ile ilgili geçen “...teftîş idüp göresiz; ... mezbûrun zulm ü te'addîsi şer'le sâbit olursa erbâb-ı hukûka müteveccih olan hukûkı alıvirdükden sonra tevzîr ü telbîsine müte'allik husûsı dahı onat tetebbu' idüp kazıyyesi neye müncer olursa kendüyi habsden itlâk itmeyüp üzerine sübût u zuhûr bulan mevâddı ... arzidesiz." "101 ifadeleri, söz konusu naib hakkında yargılamanın bulunduğu bölgede yapıldığını göstermiştir. Buna göre naibler, haklarındaki suçlamalarla ilgili görev yaptıkları bölgede yargılanabildikleri gibi merkezde de davaları görülebilmiştir.

Naiblerin teftişi, mehayif müfettişleri tarafından da yürütülebilmiştir: "Hudâvendigâr Sancağı Beği Abdurrahmân Beğ'e ve Kütâhiyye kâdîsına hüküm ki: ...sancaklarında sancakbeği sübaşıları ve zü 'amâ vü kuzâtu nüvvâbu sipâhî ... re'âyâya zulmü te'addîleri olup ... sancaklarun mezâlimü mahâyifi teftîşin sana emridüp buyurdum ...varup teftîşe şürû‘ eyleyüp ... beğlerden ... kuzâtu nüvvâbdan ... beğlerbeği vü sancakbeği sübaşılarından ... sipâhî tâyifesinden ... re âyâ ve kurâ vü kasabât halkından her kimden ise gelüp da'v[âa]-yı hakk idüp tezallüm iderler ise ... teftîşü tefahhus idüp göresiz; ... her kimün ... zulmü te'addîsi sâbitü zâhir olursa ... arzeyleyesiz ... [emrüm] ne vechile sudûr ider ise ... amel oluna... arza muhtâc olmayanları şerle lâzim geleni mahallinde icrâ idüp...”102 Burada sancak beyi, subaşılar, sipahiler ile birlikte naiblerin mehayif teftişine tâbi tutulması emredilmiş olup suçu sabit olanlardan merkeze arzı gerekmeyenlerin cezalarının verilmesi; merkeze arzı gerekenlerin arz edilmesi ve verilecek emre göre hareket edilmesi bildirilmiştir.

100 BOA 5 Numaralı Mühimme Defteri, Hüküm No: 559, s. 353.

101 BOA 6 Numaralı Mühimme Defteri, Hüküm No: 380, s. 224.

102 BOA 7 Numaralı Mühimme Defteri II, Hüküm No: 1829, s. 325-326. 
Reayadan haksız kazanç elde eden naiblerin, söz konusu kazançları iade etmeleri de devlet tarafından takip edilmiştir: "Müfettiş ...’a hüküm ... Mahmûd nâm nâyib üzerinde dahı altı bin kırk akça zuhûr idüp gaybet eyleyüp ... virmekde nizấ itdükleri i'lâm olunmağın buyurdum ... nâyib-i mezbûrı dahı bi'lfíl gaybet itmiş ise şer'le buldurması lâzim olanlara buldurup getürdüp nâyib-i mezbûrı ve .... zimmetlerinde zâhir olan mâlı bi't-tamâm tahsîl itmeyince ıtlâk itmeyesin." ${ }^{03}$ Burada haksız kazanç sebebiyle teftiş edilen naibin, zimmetinde bulunan malı tamamen iade etmeden salıverilmemesi emredilmiştir.

Yine merkeze gönderilen suret-i sicillerin incelenmesi üzerine naib hakkında kürek cezası verilmiş olup cezanın uygulanması amacıyla ilgili naib ve diğer kişilerin merkeze gönderilmesinin emredildiği kayıtlar mevcuttur ${ }^{104}$. Buna göre, suç işlediği tespit edilen naiblerin yerel yöneticiler tarafından değil, merkez tarafından cezalandırıldığı durumlar Osmanlı Devleti’nde mevcut olmuştur. Bir başka kayıtta ise daha önce hapsedilmiş bir naibin hapisten çıkarılmasının merkez tarafından yörenin idarecisine emredildiği görülmektedir ${ }^{105}$. Dolayısıyla naibler hakkındaki cezalandırmalar merkez tarafından takip edilmiştir.

Naibler hakkındaki şikayetler incelenirken, şikayetlerin doğru olup olmadığı da sorgulanmıştır: "Bi'l-fíl Mar’aş Mahkemesinde Nâyib olan Şeyhî ve Kâtib Mehmed ve İsmấîl nâm kimesneler ittifâk idüp kâdî nâmına müzevver mühürler kazıdup ba'zı husûslara temessükler virüp tezvîre sülûk itdükleri Südde-i Saâdetüm'de ilâm olunmağın buyurdum ... mezkûrlar vech-i meşrûh üzre müzevver mühür kazıdup ba'zı a'yân-1 kimesnelere temessük virdükleri vâkı' midur, ... vilâyetden ve mu'temedün-aleyh kimesnelerden tetebbu' u tefahhus idüp şer ' ile tezvîrü telbîsleri sâbitü zâhir olursa habsidüp ... arzeyleyesiz; ... emrüm ne vechile olursa amel eyleyesiz. Ammâ; bu [bâ]bda mukayyed olup kendü hâllerinde ise ehl-i garaz söziyle şer'-1 kavîme muhâlif téaddî itdürmeyesiz." ${ }^{106}$ Buna göre iddiaların doğru olup olmadığının araştırılması, doğru ise naib ve beraberindekilerin hapsedilmesi ve verilecek emre göre hareket edilmesi bildirilmiş fakat iddialar doğru değil ise kötü niyetli kimselerin sözü ile haksızlı edilmemesi tembihlenmiştir. Dolayısıyla devlet; kamu görevlilerini bir

\footnotetext{
103 BOA 7 Numaralı Mühimme Defteri II, Hüküm No: 1198, s. 5-6.

104 “...Kebsûd kãdısı Karacalar nâibi ile İlyâs nâm kimesnenin ahvâlin teftiş idüp yaramazlı̆̆ına sûret-i sicîl gönderdüki ecilden küreğe emr idüp buyurdum ki: Zikr olunan üç nefer kimesneleri yarar âdemler ile gönderesin ki küreğe konulalar...” BOA 5 Numaralı Mühimme Defteri, Hüküm No: 1141, s. 644. Teftiş edilen naibin suçunun sabit olması halinde merkeze gönderilmesi yönünde bir başka kayıt: BOA 6 Numaralı Mühimme Defteri, Hüküm No: 990, s. 94-95.

105 BOA 6 Numaralı Mühimme Defteri, Hüküm No: 666, s. 377-378.

106 BOA 7 Numaralı Mühimme Defteri I, Hüküm No: 1088, s. 542-543. Aynı hususla ilgili bir başka örnek: BOA 7 Numaralı Mühimme Defteri III, Hüküm No: 2455, s. 252.
} 
yandan denetlerken diğer yandan bu kimselerin zan altında bırakılarak görevlerini icra etmelerinin engellenmesini önlemeye yönelik hareket etmiştir.

Osmanlı Devleti, naiblerin yanı sıra vermiş oldukları hükümleri de denetlemiştir: “...ve hilâf-1 şer" kazıyye hükm iden nẩibler ne makûle kimesnelerdir. Anun gibilerden müslimânlar gelüp şekvâ iderler ise şer'a muhâlif hükm itdükleri kazâyâ ne ise malûm idinüp mücesselâtdan sûretin ihrâc itdürüp tafsîl-1 ahvâllerin mufassalü meşrûh isimleriyle yazup bildiresin. Sonra anlar hakkında emrim ne vechile sâdır olur ise mûcebi ile amel eyleyesin." ${ }^{107}$

Buna göre hakkında şikâyette bulunulan naiblerin nasıl kimseler oldukları, şer’i hükümlere aykırı şekilde karara bağladıkları davalar ile ilgili malumatla birlikte ayrıntılı olarak merkeze bildirilmesi ve verilecek emir üzere hareket edilmesi Kastamonu Beyỉne ve yöre kadılarına yazılmıştır. Burada Divan-1 Hümayun'un, naiblerle birlikte naibler tarafından verilen hukuka aykırı kararları da denetlemesi söz konusudur. Zira Divan-1 Hümayun, şeriye mahkemelerinde görülen davaları bir çeşit temyiz mercii gibi tekrar görebilmiştir ${ }^{108}$. Söz konusu olayda ise naiblerin hükümlerinin şer’i kurallara aykırı olup olmadığının tespiti, davaların Divan-1 Hümayun tarafından tekrar görülmesi ile mümkündür. Bu bakımdan naibler tarafından karara bağlanan davalar da kadıların vermiş olduğu kararlarda olduğu gibi Divan-1 Hümayun tarafından tekrar incelenebilmiştir. Dolayısıyla naibler tarafından verilen kararların da devletin en yüksek yargı organı tarafından incelenmiş olması, Osmanlı Devletỉnin adaletin tesisine vermiş olduğu öneme işaret etmektedir.

Naiblerin hukuka aykırı karar vermiş olduğuna dair iddiaların geçtiğ bir başka kayıtta ise davaların yerel mahkeme tarafından tekrar görülmesi emredilmiştir. Kayıtta geçen“...Şumnı ve Hezârgrad kâdîlarına hüküm ... ahvâl-i reâyâ ziyâde ihtilâl üzre olup bu tâyifeden gayri reâyânun birbiri üzerinde hukûk-1 şer'iyyesi olup görilmesin taleb idüp; "Vilâyet hâkimlerine mürâca'at idün." dinildükde; "Maslahatımuz ihmâl idüp görivirmediler ve nâyibler hasmımuza meylidüp hılâf-1 şer ' hükmitdiler." diyüp ve ba'zı fukarâ ümenâ vü ummâl ve sâyir mübâşirîn üzerlerine şer'le isbât-1 hukûk idüp alıvirilmesin taleb itdüklerinde; "Bunlarun husûsları arza muhtâcdur." didüklerin" arzeyledügün ecilden buyurdum... Arzolunduğı gibi ise ... da'vâları kuzâtu nüvvâb hılâf-1 şer'u kânûn hükmitmiş olalar, anun gibi kazâyâyı tekrâr ... istimâc idüp şer'u kânûnla faslidüp...”109 ifadeleri çerçevesinde, denilebilir ki, Osmanlı Devleti’nde, naibler tarafından verilen

BOA 5 Numaralı Mühimme Defteri, Hüküm No: 182, s. 148-149.

Cin/Akyılmaz, s. 132.

BOA 7 Numaralı Mühimme Defteri, Hüküm No: 47, s. 22-23. 
kararlar, şikayet üzerine yerel mahkemelerce tekrar görülebilmiştir. İslam hukukuna göre ilk derece mahkemesinin vermiş olduğu kararlar kesin olmakla birlikte hukuka aykırı olduğu iddia edilen kararlar tekrar görülebilmiştir ${ }^{110}$. Buna göre Osmanlı Devleti’nde kadıların vermiş olduğu kararlar için yapılan bu uygulama naibler tarafından verilen kararlar için de uygulanmıştır. Naiblerce şeri hükümlere uygun verilen kararlar, kadı tarafından da değiştirilememiştir ${ }^{111}$.

\section{F. NAİBİN AZLEDİLMESI}

Osmanlı Devleti'nde naibler, kadılar tarafından atandığı gibi yine kadılar tarafından azledilmiştir ${ }^{112}$. Naiblerin azledilmesi hususuyla ilgili şeriye sicillerinde yer alan önemli bir örneğe aşağıda yer verilmiştir:

“... mektub gönderüp kazâ-i mezbûrda muhzır olan ... Veli ve ... Abdal nâm kimesnelerden ahâlî̀-i vilâyet meclis-i şer'a ... "mezbûr yigirmi otuz yıllık nâ'ib ve muhzırlardır. Zarar-ı âmları vardur", deyü ref'olunmaların arz itdüğ̈̈n ecilden buyurdum ... Nüvvâb ve muhzırların azlu nasbı kuzâta müfevvezdir. Eger bu ma'lûmun ise arz etmene bâ'is nedir, niçün te'addî olanları def' etmezsin? Eger ma'lumun değil ise ma'lûm idinüp dahi kazâna tâbi'olan eger nâ'iblerdir ve eger muhzırlardır anun gibi re'âyâya te'addî olanları ref' eyleyesin." 113

Buna göre Gerger kadısı, yanında çalışan naib ve muhzırla ilgili görevden alınmaları için Divan-1 Hümayun'a şikâyette bulunmuş; verilen cevapta naib ve muhzırları atama ve azletme yetkisinin kadının kendisinde olduğu belirtilmiştir. Burada kadının bu hususu bilmemesinden ziyade uzun sürelerle o bölgede görev alan naib ve muhzırların görevden alınmasında güçlük yaşayabileceğini düşünerek hareket etmiş olduğu değerlendirilmektedir. Buna göre yirmi otuz yıl gibi sürelerle o bölgede görev alan ve halka zulmettikleri anlaşılan bu kişilerin nüfuzlu olması ihtimali çerçevesinde kadı, merkezden alacağı bir emrin, muhzır ve naibi görevden almasını kolay-

110 Ekinci, Ekrem Buğra (2001) Ateş İstidası İslam-Osmanlı Hukukunda Mahkeme Kararlarının Kontrolü, İstanbul, Filiz Kitabevi, s. 40-43.

111 Ebussuud tarafindan verilen ve bu hususa işaret eden bir fetva: "Zeyd-i kadl, naibi Amr'in Şer'a muvafik hükmünü tağyire kadir olur mu? Cevap: Olmaz." Avcı, s. 107.

112 Akman, s. 43.

113 Akman, s. 43; Demir, s. 44; BOA 5 Numaralı Mühimme Defteri, Hüküm No: 282, s. 209. 
laştırabileceğini düşünmüş olmalıdır ${ }^{114}$. Zira Osmanlı Devleti'nde kadıların görev aldıkları bölgedeki idarecilerle ilgili uyuşmazlıklarda, merkezin çözümüne başvurmuş olduğu bir gerçektir.

Bununla birlikte naibin görevini kötüye kullanması halinde merkez, ilgili naibi azletmesi için kadıyı ikaz edebilmiş, bu hususta kadıya emir verebilmiş ya da bizzat naibi görevden alabilmiştir. Örneğin 1560 tarihli Sivas Beylerbeyi'ne yazılan bir mühimme kaydında Sivas'ta görev yapan naibin kanuna aykırı davranmasından ötürü azledilmesi için kadıya hükm-i şerif gönderildiği fakat naibin halen görevde olduğunun duyulduğu; beylerbeyi tarafından söz konusu emrin uygulanıp uygulanmadığının kontrol edilmesi, eğer söz konusu naib görevde ise şu an görev yapmakta olan kadı tarafından mı yoksa daha önce görev yapmış olan kadı tarafından mı görevlendirilmiş olduğu, halen görevli olan kadı tarafından görevlendirilmiş ise naibin ne kadar süredir görevde olduğu, söz konusu naibin emre aykırı olarak görevlendirilmesinin sebebinin ne olduğu hususlarını öğrenerek merkeze bildirmesi ve daha sonra verilecek emre göre hareket etmesi belirtilmiştir ${ }^{115}$. Görüldüğü üzere padişah vermiş olduğu emrin uygulanmamış olmasının nedenlerini ayrıntılı şekilde teftiş ettirmiştir. Özellikle naibin hangi kadı tarafından görevlendirilmiş olduğunun üzerinde durulması, emre aykırı hareket edilip edilmediğinin belirlenmesi bakımından önemlidir. Yine bir başka örnekte geçen “...nâyibün rêâyâya zulmü ... olup niyâbetden ref" olunmak içün ahkâm-ı şerîfe virilmişiken ref" olunmamağa sebeb nedür, re'âyâya zulmü ... olmayup şikâyet idenler hılâf-ı vâkı 'mı şikâyet iderler, yohsa ... ahkâm-ı şerîfeyi kendü satun mı almışdur, aslı nedür; ... arzidesin." ${ }^{\prime 16}$ ifadeleri, görevden alınması emredilen naibin neden hala görev aldığg ve şikayet-

114 Bu yorumumuza açıkça işaret eden bir başka örnek: "Bağdâd beğlerbeğisine ve Bağdâd kâdîsına ve Mendelic kâdîsına hüküm ... Sen ki Mendelic kâdîsısın, ... mektûb gönderüp; "Nâyib olan Abbâs on beş yıldan ziyâdedür ... nâyib olup re 'âyâya zulmi olup niyâbetden ref" tyçün hükm-i şerîf gelüp ref" olunup ümerâ ve ba 'z a yân mu în olmağla girü nâyib olup fukarâya zulm ... eylemekden hâlî olmaduğın” bildürmişsin; "niyâbetden ref" olmağıçün hükm-i şerî recâ eyledüklerin” arzitmişsin. Buyurdum ... husamâsıyla berâber idüp ... kazlyyelerin şer 'le göresin; ... te 'addîsi sâbit olursa niyâbetden ref' idesin.” BOA 7 Numaralı Mühimme Defteri II, Hüküm No: 1842, s. 331. On beş yıldan fazla aynı yerde görev almakta olan naib daha önce azledilmesine rağmen ümeradan ve ayandan bazı kişilerin yardımları ile tekrar göreve başlamış ve yöre kadısı tarafından ilgili naibin azli için merkezden hükm-i şerif istenmiştir.

115 BOA 3 Numaralı Mühimme Defteri, Hüküm No: 1409, s. 624-625. Emre aykırı işler yapan naibin görevden alınmasının merkez tarafından emredildiği başka örnekler: BOA 6 Numaralı Mühimme Defteri, Hüküm No: 385, s. 226; BOA 7 Numaralı Mühimme Defteri I, Hüküm No: 1005, s. 501.

116 BOA 6 Numaralı Mühimme Defteri, Hüküm No: 1230, s. 227. 
lerin doğru olup olmadığı hususlarının araştırılmasını emretmektedir. Burada merkezin, her ne kadar görevden alma emri vermiş olsa da iddiaların gerçek olup olmadığının tekrar araştırılmasını istemesi, haksız uygulamaya mahal verilmemesi adına önemlidir.

Yine aşağıdaki mühimme kaydına göre görevine uygun hareket etmeyen naibin görevden alınarak teftiş edilmesi, üzerinde hak iddia edenlerin davalarının görülerek haklarının iade edilmesi merkez tarafından emredilmiştir:

"Koca-ili begine ve Üsküdar kadısına hüküm ... suret-i sicil gönderüp kaza'-i mezburda Na'ibü'ş-Şer olan Abdi ... ağaç tevzi'inde ...nam kimesnenün buğdayın alup, taleb idüp inkar eyledükde udul-i Müsliminden şehadet itdüklerin i’lam eylemişsin. İmdi, buyurdum ... mezbura emrüm mucebince min-ba'd niyabet itdürmeyüp teftişe habs ile alup gidüp ă̆aç tevzi'i hususin dahi mezburdan hak da'va ider kimesne varsa husama muvacehesinde ...teftiş idüp ... hakların alıviresin. Ba'de't-teftiş sabit olan mevaddın mufassal... arz idesin... emrüm ne veçhile olursa ... amel eyleyesin." "117

Ankara Mirlivasiyle Ankara ve Murtazabad kadılarına hitaben yazılan 15 Haziran 1589 tarihli bir fermanda ise naib, merkez tarafından azledilmiş ve bu husus ilgili kadıya bildirilmiştir: "Zulmü haber alınan Murtazabad Naibi'nin azledildiği, bu emrin geleceklere örnek ve ibret olmak üzere Murtazabad mahkemesi siciline kayd, aslinın ise mutemet bir kimseye verilmesi" ${ }^{118}$. Bir başka mühimme kaydında ise hukuki bir meselede hilesi görülen naib hakkında "...sen ki kadısın, mezbura ... niyabet itdürmeyüp, bu hükm-i hümayunumun suretin sicill-i mahfuza kayd idesin ki min bad ... kim kadı olursa ... mezbura niyabet itdürmeyeler." ${ }^{119}$ şeklinde emir verilmiştir. Daha sonra kadı olanların da söz konusu naibi görevlendirmemesi amacıyla, naib hakkındaki hükmün suretinin sicile kaydedilmesi, Osmanlı Devleti'nde usulsüz hareket eden naiblere karşı titizlikle hareket edildiğine ve adalet işlerinde

117 BOA 3 Numaralı Mühimme Defteri, Hüküm No: 717, s. 317. Aynı hususla ilgili örnekler: BOA 5 Numaralı Mühimme Defteri, Hüküm No: 42, s. 66; BOA 6 Numaralı Mühimme Defteri, Hüküm No: 903, s. 54.

118 Arık, Feda Şamil (1997) “Osmanlılarda Kadılık Müessesesi 1", Ankara Üniversitesi Osmanlı Tarihi Araştırma ve Uygulama Merkezi Dergisi, Sayı: 8, s. 22; Demir, s. 44; Ongan, Halit (2014) Ankara'nın İki Numaralı Şer'iye Sicili, 2. Baskı, Ankara, Atatürk Külttür, Dil ve Tarih Yüksek Kurumu Türk Tarih Kurumu Yayınları, s. 80 .

119 BOA 3 Numaralı Mühimme Defteri, Hüküm No: 1636, s. 728-729. Aynı hususla ilgili bir başka örnek: 7 Numaralı Mühimme Defteri II, Hüküm No: 1197, s. 5. 
usulsüz davranan naibin bir daha görev almaması için özen gösterildiğine işaret etmektedir.

Bir başka kayıtta ise hukuka aykırı hareket eden naib azledilmekle kalmamış ayrıca sürülmüştür. 1561 tarihli söz konusu vakıada sahtekarlık yaptığı şikâyeti üzerine hakkında teftiş yapılan ve suçu sabit olan naib bulunduğu yerden Rodos'a sürülmüştür ${ }^{120}$. Buna göre naibler hukuka aykırı işlem yaptıklarında ayrıca sürgün cezası ile cezalandırılabilmiştir.

Sonuç olarak Osmanlı Devleti'nde naibler kadı tarafından azledilmekle birlikte, hukuka aykırı hareket eden, kendi hesabına çıkar sağlayan, halka zulümde bulunan ve hakkında şikâyet olan naiblerden suçu sabit olanlar bizzat merkez tarafından azledilebilmiştir.

\section{G. NAİBLİK KURUMUNUN YOZLAŞMASI}

Adli teşkilatta önemli bir yer teşkil eden naiblik kurumu, çeşitli sebep ve uygulamalarla yozlaşmıştır. Bu sebepler arasında naiblerin yetersiz kişiler arasından atanması, naiblerin naib atamasının sıklıkla uygulanması, taşra yönetiminde görev alan kamu görevlilerinin naib ataması, naiblerin uzun süreler görev yapması ve naibliğin iltizam usulü satılması gibi hususları sayabiliriz.

Gerçekten de yetersiz kişiler arasından naib atanması usulü devletin son zamanlarında sıkça uygulanmıştır. Mevali derecesindeki kadı ve müderris çocuklarına, yeterli bilgi sahibi olup olmadıklarına bakılmadan müderrislik veya kadılık verilmiş olup bu kişiler de yerlerine naib atamıştır ${ }^{121}$. 19. yüzyılın sonlarında Hicaz Bölgesi hakkında Yıldız Sarayına sunulmuş olan bir raporda, bölgede yeni ve donanımlı mektepler kurulması, bu mekteplerden şehadetname alarak mezun olmamış şeyh, kaymakam, müderris ve kaza naibi gibi görevlilerin çocuklarının, babaları yerine göreve getirilmemesi gerektiği belirtilmiştir ${ }^{122}$. Buna göre, yörede yargılama yapmakla görevli kaza naiblerinin çocuklarının, eğitimli olup olmamasına bakılmadan babaları yerine kaza naibi olarak görevlendirilebilmiş olduğu görülmektedir. Dolayısıyla eğitimsiz kişilerin naib sıfatıyla yargılama yapmasının, bu kurumun yozlaşmasında önemli bir etken olduğu söylenebilir.

BOA 3 Numaralı Mühimme Defteri, Hüküm No: 1640, s. 730-731.

121 Demir, s. 44.

122 Akşin Somel, Selçuk (1996) “Osman Nuri Paşa’nın 17 Temmuz 1885 Tarihli Hicaz Raporu”, Tarih Araştırmaları Dergisi, Cilt: 18, Sayı: 29, s. 19. 
Yine naibler, kendi yerlerine naib atayarak, ehil olmayan kişilerin adli teşkilatta yer almasını kolaylaştırmıştır. Bu yöntemin sıkça uygulanmış olduğu şeriye sicillerinden anlaşılmaktadır. Örneğin 1761 yllı Ağustos ayında eski İstanbul kadısı Ladiki zade Fevzullah Nazif Efendi'ye arpalık olarak tahsis edilen Antep kazasında görev yapmakta olan Antep naibi Vaiz zade Mehmet Efendi, aynı tarihte Mevlana Hacı Mustafa Efendi'yi Antep naibi olarak atamıştır ${ }^{123}$. Yine Diyarbakır kadılığında naib tarafından atanmış bab naibi olduğu şeriye sicil kayıtlarından anlaşılmıştır. Buna göre 13 Mart 1792 tarihinde Diyarbakır kadılığına tayin edilen Mehmed Emin Efendi, naib olarak Mevlana Osman Efendi'yi atamış olup Mevlana Osman Efendi de aynı tarihte Diyarbakır mahkemesinde baş katip olarak görev yapan es-Seyyid Abdulkadir Efendìyi bab naibi olarak atamıştır ${ }^{124}$. Bu şekilde naibin naib atamış olması, adalet mekanizmasının gereği gibi işlemesine engel teşkil etmiş, yargı teşkilatında yetersiz kişilerin yer almasının önünü açmıştır.

Naib atanmasının gecikmesi gibi sebeplerle, bölge halkının adli işlerini yürütmesi amacıyla geçici de olsa yörenin valisi tarafından naib atanması, şeriye sicillerinde karşılaşılan durumlardandır ${ }^{125}$. Vali tarafından atanan naibin, reayanın vali hakkında yaptığı şikayetleri değerlendirirken tarafsız olmayacağı aşikardır. Bu sebeple vali gibi kamu görevlilerinin görev almış oldukları yörelerde, adaleti sağlayacak olan naibi ataması, bu kurumu yozlaştıran etkenlerden olmuştur. Yine bazı bölgelerde naib olarak sürekli belirli kişilerin atanmass ${ }^{126}$ bunların çok uzun sürelerle görevde kalması sonucunu doğurmuştur. Aynı bölgede uzun süre görev alan naibler de nüfuzunu arttırarak reaya üzerinde baskı kurabilmiştir. 1566 tarihli bir mühimme kaydı bu hususa açıkça işaret etmektedir: “... mektûb gönderüp ... Niğde'de nầib olan Carullah yirmi yıldan mütecaviz niyâbet idüp müslimanlarun ve keferenin evşen tarikiyle akçelerin alup def'i lâzımdır deyü bildirmişsin buyurdum ... arz olunduğu gibi ... nầibin ... téaddisi varsa niyabetden def'idesin."127 Söz konusu kayıtta adı geçen naibin yirmi yıldan fazla görev yapmış olduğu yerde reayanın akçesini haksız şekilde aldığı belirtilmiştir. Merkez tarafından verilen emirde ise iddianın doğru olması halinde naibin görevden alınması bildirilmiştir.

Yukarıda bahsetmiş olduğumuz gibi, kadılar, yargı bölgelerindeki nahiyelere naib tayin etme yetkisine haiz olmuştur. Kadılar bu yetkilerini kötüye

123 Demir, s. 44; Gaziantep Şer’i Mahkeme Sicillerinden Örnekler (1970) Cilt: 81-141, Miladi 1729-1825, Hazırlayanalar: Güzelbey, Cemil Cahit/Yetkin, Hulusi, Gaziantep, Gaziantep Kültür Derneği Kitap ve Broșür Yayınları, Sayı: 55, s. 71.

124 Yılmazçelik, s. 234-235.

125 Saydam, s. 302.

126 Saydam, s. 300.

127 BOA 5 Numaralı Mühimme Defteri Hüküm No: 1481, s. 800. Yirmi yıldan fazla aynı yerde görev alan naibin reayaya zulmü hakkında bir başka kayıt: BOA 6 Numaralı Mühimme Defteri, Hüküm No: 1195, s. 209. 
kullanmaya başlamış olup bu hususta devletin ekonomisinin bozulması da etkili olmuştur. Gerçekten de Fransız İhtilali ile dünyada ve özellikle Avrupa’da gerçekleşen değişimler, sanayi devrimi de eklendiğinde Osmanlı ekonomisini olumsuz etkilemiş; bu durum yargı sisteminde de kendisini göstermiştir. Daha önce naiblik bulunmayan bölgelere gelirini satmak amaçlı naiblikler kurulmaya başlanmıştır. Buna göre kadı, atamış olduğu naiblerden, atadığ 1 bölgenin resim bedelini peşin olarak almıştır. Bu uygulamaya naibliklerin iltizam usulüyle satılmass ${ }^{128}$ denilmiştir. İltizam usulü ile naibliği satın alan ve çoğu ehliyetsiz ve eğitimsiz olan kişiler ise vermiş olduğu bedeli çıkarmak ve üstüne daha fazla kâr elde edebilmek için çeşitli usulsüzlüklere başvurmuştur. İltizamla naiblik yapanların halktan haksız kazanç sağladığı bir olayla ilgili merkez, söz konusu niyabetin iltizamla verilmemesini emretmiştir ${ }^{129}$. Yine nahiyelerde resim toplamak amaçlı sık sık devreye çıkan naibler, kendileri, hayvanları ve beraberindeki kişilerin yeme içmesini halka karşılatmış olup bu durum halkı güç duruma düşürmüştür. Örneğin Aydın sancak beyi tarafından merkeze yazılan yazıda "köhne ve mürteşi" kişilere naiblik verildiği, bu kişilerin "il üzerine çıkarak" halka zulmettiği bildirilmiş, merkezden yazılan 27 Temmuz 1560 tarihli cevapta ise sancak beyine, bu şekilde naiblerin devreye çlkmasına engel olma yetkisi verilmiştir. 18. yüzyılın yarısından itibaren ise naibler, ayanlarla anlaşarak veya korkarak, ayanların halka fena muamelelerine göz yummuş, bu yönde ilamlar düzenlemiştir ${ }^{130}$. Örneğin Güzelhisar naibi Mehmet Lütfullah Efendi, para ile usulsüz voyvoda tayin ettirmesi, halktan usule aykırı vergi toplatması ve benzeri uygunsuz hareketleri sebebiyle Ankaràya sürgün edilmiştir ${ }^{131}$.

Naiblerin, görevden alınmış olmalarına rağmen usulsüz yollarla elde ettikleri hükm-i şerifler ile göreve devam edebilmiş olmaları, kurumun yozlaşmasındaki bir başka sebeptir. 1570 tarihli bir kayıt, bu duruma açıkça işaret

128 Naiblik görevinin iltizam usulü satısıına bir örnek: "Sebeb-i tahrir-i kitab ve bais-i tastir-i sutur-ı hitab oldur ki ... Mustafa Beg ... tarafindan fahrü'l-ümera' Hasan Kethüda meclis-i şer'e hazır gelüb şehr niyabetini Sadaka bin Tator'a seb'a yllinin Rebi'ü'l-evvel'in on ikinci gününden kirk alt bin akçe üzerine mukata'aya virdi, yava ve beytü l-mal ve bundan gayn şol ki sitasetdür ol begün ol. Vakta ki kaziyye bu minval üzre cari oldu ki mezkur Sadaka dahi mesfur meblağı mah-be mah iltizam gösterdiği ecilden mezkur kethüdanun iltimaslyla deftere kayd olund ... meblağ-ı mezkurdan beş yüz akçeye eşhür var, yıl tamam oluncaya bu hil'at bahasından ötürü ve dahi mezkur Sadaka'nun nefsine Cerrah Kerem kefil olmuşdur ki her ne vakt taleb olunursa teslim eyleye.” Şer'iye Sicilleri Seçme Hükümler (1989) II. Cilt, İstanbul, Türk Dünyası Araştırmaları Vakfı, s. 215-216.

129 "Misır beylerbeyisine hüküm ki: Rıkâb-ı hümâyûnıma ruk'a sunulup Menâzle kadısı olan kimesne niyâbeti aharlara iltizâma virilmekle nâ'ib olanlar müslümanlardan hilâf-ı șer 'ü kãnûn haylı zülmü ta 'addîler idüp akçalardan almakdan hâli olmazlar imiş eyle olsa buyurdum ki: Hükm-i şerîfim vardukda göresin fi'l-vâki ' kãdl$\iota$ mezbûr niyâbeti iltizâma virmiş ise men ' idüp tenbîh eyleyesin ki iltizâma virlmeyüp mu'temedün aleyh kimesnelere zabt? itdire şöyle bilesin. ” BOA 5 Numaralı Mühimme Defteri, Hüküm No: 1685, s. 897.

130 İnalcık, s. 76; Uzunçarşll, s. 122; Arık, s. 64; Feyzioğlu/Kılıç, s. 36-37.

131 Çadırcı, Musa (1981) "Tanzimat'ın İlanı Sıralarında Osmanlı İmparatorluğunda Kadılık Kurumu ve 1838 Tarihli Tarık-1 İlmıyye'ye Dair Ceza Kanunnamesi”, Tarih Araştırmaları Dergisi, Cilt: 14, Sayı: 25, s. 142. 
etmektedir. Merkezden yazılan söz konusu kayıtta, adı geçen naibin görevden alınması, bu hususun sicile kaydedilmesi ve İstanbul'dan hüküm getirse dahi bu belgenin merkeze gönderilmesi bildirilmiştir: “... kasaba-i mezbûrede nâyib olan ... Mustafâ ... içün; "Envấ-ı fesâd ü şenấat ile mevsûf olup niyâbet hıdmetine değil, belki vücûdınun izâlesi lâzim." didükleri ecilden ahvâli tefahhus olunup fi'l-vâkk didükleri mertebeden dahı ziyâde şenấatü kabâhati olduğı mukarrer olmağın niyâbetden ref" olunduğın" bildürüp; "min-bad dahı niyâbet olmamastyçün" emr-i hümâyûnum" taleb eyledüğün ecilden buyurdum ... mezkûra min-ba'd niyâbet itdürmeyüp ... bir tarîkla Südde-i Saâdetüm'den ... hükm-i şserîf ibrâz iderse ... elinden alup Südde-i Saâdetüme gönderüp aslâ niyâbet itdürmeyesin ... bu hükm-i hümâyûnumı sicill-i mahfûza kaydidüp ve bu hükm-i şerîfümi kasaba halkı muvâcehesinde ayân-ı kasabadan bir mu'temedün-aleyh kimesnenün elinde ibkâ idesin ki, vâkı' olan kuzâta ibrâz idüp niyâbet itdürmeyeler."132

III. Selim döneminde ulemanın durumunun düzeltilmesi amacıyla yapılan bazı çalışmalarda naibler hakkında da yeni düzenlemeler getirilmiştir. Önde gelen ulemanın da katıldığı toplantılarda kadı ve naiblerin durumları görüşülmüş ve yapılması gerekenler hakkında bir ferman çıkarılmıştır. Buna göre arpalıkların iltizam usulü ile değil emanet usulü ile yeterli ve insaflı naiblere verilmesi emredilmiştir. Yine hasta ya da ihtiyar olanlar dışında kadıların görev yerine naib atamayıp kendilerinin gitmesi fermanda düzenlenmiş olan bir diğer husustur ${ }^{133}$. Ayrıca aşçı, hizmetkar gibi kimselere naiblik verilmemesi de yine III. Selim döneminde çıarılan 1792 tarihli kanunda düzenlenen hususlardan olmuştur ${ }^{134}$. Kanunlarda yer alan bu tip düzenlemeler, adli teşkilatta naib sıfatıyla ne denli adaletten uzak kimselerin görevlendirilmiş olduğunu göstermektedir. Bu şekilde aşçı, hizmetkar gibi kimselerin naiblik görevini elde etmesi söz konusu kurumun bozulmasını kaçınılmaz kılmıştır.

Yine II. Mahmut'un, bozulan adalet sistemini düzeltmek amacıyla yapmış olduğu düzenlemelerden biri olan 1838 tarihli Tarık-i İlmiye Mahsus Ceza Kanunname-i Hümayunu'nda rüşvetle naib atanmasının cezası düzenlenmiş, ayrıca karar makamının iltimas veya rüşvetle değil tarafsı şekilde hareket etmesi gerektiği belirtilmiştir ${ }^{135}$. Dolayısıyla 19. yüzyıl düzenlemesi olan söz konusu kanunname, o dönem itibariyle rüşvet ve çıkar sağlama yoluyla da naib

132 BOA 12 Numaralı Mühimme Defteri I, Hüküm No: 613, s. 404-405.

133 Çadırcı (1991) s. 80

134 Uzunçarşılı, s. 122; Gür, A. Refik (2015) Osmanlı İmparatorluğu'nda Kadılık Müessesesi, Hazırlayan: Aryol, M. Nihat, İstanbul, Türkiye İş Bankası Kültür Yayınları, s. 69.

135 Çadırcı (1981) s. 142; Ünal Özkorkut, Nevin (2008) "Yargı Bağımsızlığı Açısından Osmanlı'da ve Günümüz Türkiyesi’nde Yargıya Genel Bir Bakış”, Ankara Üniversitesi Hukuk Fakültesi Dergisi, Cilt: 57, Sayı: 1, s. 233. 
atamalarının gerçekleştirildiğini ve yine naiblerin kanun hükümleri dışında rüşvetle de hareket edebilmiş olduklarına işaret etmektedir.

Sonuç olarak naib tayin etme usulü, 1915 yılında sona erdirilmiş olup Cumhuriyet döneminde şeriye mahkemelerinin yürürlükten kaldırılması ile naiblik kurumunun görev alanı ve bu mahkemelerde görev alan naibler de tamamen ortadan kalkmışıır'136.

\section{TANZIMAT DÖNEMİ OSMANLI YARGI TEŞKİLATINDA NAİB}

Osmanlı Devleti kurumları Tanzimat dönemi öncesi ve sonrasında büyük farklılık teşkil etmiştir. 17. yüzyıl itibariyle devletin zayıflaması sonucu diğer kurumlarla birlikte yargı teşkilatı da etkilenmiştir. Medreselerde yaşanan bozulma bu durumun başlıca sebebidir. Yüksek medreselerden mezun olarak alınabilen müderrislik derecesi, ulema çocuklarına henüz doğduklarında verilmiş, okuma yazma bilmeyenler mülazımlık belgesi satın alabilmiştir. Yine yüksek dereceli kadılıklara atanan kadılar, atandıkları bölgelere gitmemiş, yerlerine naib atamıştır. $\mathrm{Bu}$ durum, yüksek dereceli kadının ve naibin eğitim düzeyindeki büyük farklılık sebebiyle yargıdaki yozlaşmada büyük rol oynamışıır' ${ }^{137}$.

Tanzimat döneminde naibler hakkında da yenilikler yapılmıştır. $\mathrm{Bu}$ bağlamda 1838 tarihli Tarik-i İlmiye Dair Ceza Kanunnamesỉnde kadılık mesleğini icra edenler ve bu mesleğe yeni adım atacak olanlar için sınav getirilmiştir. Ancak üç ay sonra söz konusu sınavın yalnızca mesleğe yeni başlayacaklar için uygulanacağına dair Ceza Kanunnamesỉne bir Zeyl çıarılmıştır. Yine bu dönemde daha nitelikli naibler yetiştirmek amacıyla 1855 yılında Muallimhane-i Nüvvab adlı bir mektep kurulmuştur. Öğrenci sayısı, öğrenim süresi, ders programında çeşitli tarihlerde değişiklikler yapılan söz konusu mektebin adı daha sonra sirasıyla Mekteb-i Nüvvab, Mekteb-i Kuzat ve Medresetü'l-kudat şeklinde değiştirilmiştir ${ }^{138}$.

Burada belirtmek gerekir ki, Tanzimat Dönemi itibariyle artık kadıların yerini naibler almış ${ }^{139}$, Osmanlı Devleti’nde hâkim sıfatıyla naibler zikredilmeye başlanmıştır. 1855 tarihinde çıkarılan Nüvvab Nizamnamesi tasarısında yer alan

136 Demir, s. 44; İpşirli (2006) s. 313.

137 Üçok/Mumcu/Bozkurt, s. 241-244.

138 Yurdakul, İlhami (2016) İslam Ansiklopedisi, “Mekteb-i Nüvvab”, Türkiye Diyanet Vakfi İslam Araştırmaları Merkezi, Cilt: Ek-2, s. 242-243.

139 Çadırcı, Musa (1991) Tanzimat Döneminde Anadolu Kentlerinin Sosyal ve Ekonomik Yapıları, 1. Baskı, Ankara, Atatürk Kültür, Dil ve Tarih Yüksek Kurumu Türk Tarih Kurumu Yayınları, s. 279. 
gerekçelerde ${ }^{140}$ kadılarla ilgili sorunların dile getirilmesi ve fakat nizamnamenin adının "Nüvvab Nizamnamesi” şeklinde konulması, bu hususu desteklemektedir. 1855 tarihli Nüvvab Nizamnamesi ile naiblerin atama ve azledilme usulleri tekrar düzenlenmiş olup çeşitli sınavlar getirilmiştir. Naib olabilmek için İstanbul mahkemelerine devam ederek hâkimden liyakate dair bir belge almak ve ulemanın katıldığı kurullarda sınava girerek başarılı olmak şartı getirilmiştir. Mahkemeler beş sınıfa ayrilmış ve naibler de yeterliliklerine göre bu mahkemelerde görevlendirilmiştir. Buna göre sınavla ilk defa mesleğe kabul edilen naib beşinci sınıf naib olarak beşinci derecedeki mahkemelerde görev alacaktır. Görev süresi bittiğinde sınava girerek başarılı olması halinde bir üst derecedeki mahkemelerde görev alabilecektir. Ayrıca görev süreleri, görev alınan belde ve kazaların şehir merkezlerine uzak olması halinde 24 ay, uzak olmaması halinde 18 ay olarak belirlenmiştir. Şeriat ve kanun dışı işlem yapan naibler görevlerinden azledilecek ve ceza kanununa göre cezalandırılacaktır ${ }^{141}$. Nizamname ile naiblerin ehil kimseler arasından seçilmesi ve mesleklerini sürdürdükleri sürece yeterliliklerinin korunması amaçlanmıştır. $\mathrm{Bu}$ durum, adli teşkilatta yetersiz kimselerin görev aldığını ve Osmanlı tarafından bu durumun kabul edilerek söz konusu kimselerin ayrıştırılması için çalışma başlatıldığını göstermektedir.

\section{SONUÇ}

Naib, Osmanlı Devletỉnde olduğu gibi daha önceki İslam ve Türk İslam devletlerinde de bulunmuş önemli bir kamu görevlisidir. "Birinin yerine geçen, vekil” anlamına gelen naib, İslam devletlerinde daha çok idari görevlilerin kendi yerlerine vekaleten görevlendirmiş oldukları kimseler için kullanılmıştır. Osmanlı Devletỉnde ise daha çok adli teşkilatta kadının yardımcısı olup kadıya vekaleten dava dinlemekten çeşitli idari görevlere kadar oldukça geniş görev yelpazesi bulunan kimseler için bu ifade kullanılmıştır.

Adli teşkilatta önemli bir yere sahip olan naibler, medrese eğitimini almakla yükümlü tutulmuştur. Bu husus medreselerin İslami kimliği göz önüne alındığında Osmanlı Devleti’nde yalnızca Müslümanların naiblik görevine atanmış olduğuna işaret etmektedir.

Osmanlı Devletỉnde naibler kadı tarafından atanmış ve azledilmişlerdir. Fakat şeriye sicillerinden anlaşıldığı üzere Osmanlı, adaleti sağlamak adına bazı hallerde naibini azletmesi yönünde kadıyı uyarabildiği gibi reayanın talebi doğrultusunda belirli kişilerin naib olarak atanmasını da kadıdan isteyebilmiştir.

\footnotetext{
140 Bal, Emel Bengü (2016) “Tanzimattan Sonra Kadı ve Naip Yetiştirmek Amaciyla Kurulan Okul: Mekteb-i Nüvvab", (Yayımlanmamıș Yüksek Lisans Tezi), Sakarya Üniversitesi Sosyal Bilimler Enstitüsü, s. 39-40. 
Ayrıca kadılar bu yetkiye haiz olmalarına rağmen reayaya zulmeden nüfuz sahibi naibinin görevden alınmasını merkezden isteyebilmiştir. Naiblerin, atanacağı yöre halkından olmaması kural olmasına rağmen bu kurala aykırı uygulamaya sıklıkla rastlanmış, 1838 tarihli Tarik-i İlmiyeye Mahsus Ceza Kanunname-i Hümayunu ile Osmanlı bu kuralı kaldırmıştır. Naibler atanmış oldukları mahkemenin iş yüküne göre birden fazla sayıda olabilmiştir. Bu durum özellikle İstanbul'da görülmüş olsa da farklı bölgelerin şeriye sicil kayıtlarında da bu duruma rastlanılmıştır. Yine naibler belirli bir süre veya görev için atanmıştır. Fakat özellikle arpalık kazalarında otuz yıl gibi uzun sürelerle belirli birkaç kişinin naiblik yaptığı görülmüştür. Naiblerin bu şekilde uzun sürelerle görevde kalması ve yöre halkı arasından atanması adaletin tesisini olumsuz etkilemiştir.

Naiblerin icra ettikleri görevler, kadı yerine şeriye mahkemelerine atanmaları veya kadı yanında yardımcı sıfatıyla görev yürütmeleri halinde farklılık göstermiştir. Kadı yerine atanan naibler mahkeme başkanlığını yürütmüş ve kadının sahip olduğu bütün yetkilere haiz olmuştur. Alacak ve cinayet davaları dahil olmak üzere bütün davaları görmüş, miras taksimi yapmış, vasi tayin ve azletmiş, vasiyet hükümlerine ve vakıf senetlerine uygun hareket edilmesini denetlemiş, görev aldıkları yörelerde kimi kamu görevlilerinin atanmasında rol oynamışlardır. Kadı yerine atanan naibler, görev aldıkları mahkemeler çerçevesinde bab naibi, mevali naibi ve arpalık naibi gibi sıfatlarla da anılmıştır. Kadının yanında kadı yardımcısı sıfatıyla görev yapan naibler, kadının verdiği vekalet çerçevesinde adli işlemleri yürütmüştür. Kadı dava görme yetkisi vermiş ise söz konusu naib, kadı gibi davaları görmüştür. Dava görme yetkisi verilmeyen naib ise davacı, davalı, şahitleri dinlemek, şahitler hakkında güvenilirlik soruşturması yapmak gibi işleri yürütmüştür. Naibler keşif için mahkeme tarafından görevlendirilmiş oldukları gibi reaya veya subaşı gibi kamu görevlileri tarafından talep olması halinde de keşfe çıkabilmiştir. Mahkeme, keşifle görevlendirmiş olduğu naibi, söz konusu uyuşmazlığ1 çözmekle de yetkilendirebilmiştir. Fakat naibin keşif sonrası vermiş olduğu hükmün kadı tarafından da onaylandığı örnekler şeriye sicillerinde mevcuttur. Kadı yanında görev yapan naiblerin hüküm vermekle yetkilendirilmiş olmalarına rağmen kararlarının kadı tarafından denetlenmesi; verilen hükmün daha ehil ellerden geçerek adaletin tesis edilmesi bakımından önemlidir. Son olarak kazalara atanan kadılar iş yükünün fazla olması sebebiyle kazaya bağlı nahiyelere, kaza naibleri atamıştır. Kaza naibleri bu bölgelerde kadı adına adli işleri yürütmüş aynı zamanda söz konusu bölgelerde meydana gelen olaylardan kadıyı haberdar etmiştir.

İstanbul kadılığında iş yükünün çokluğundan dolayı yapmış oldukları 
işlerle anılan çeşitli ve çok sayıda naib bulunmuştur. Bunlar; ayak naibi, gece naibi, yağ naibi, bab naibi, çardak naibi, mum naibi, kapan naibi, avarız naibi, keşif naibi ve pastırma naibidir. Söz konusu naibler, görev alanları ile ilgili uyuşmazlıkların çözümlenmesiyle de yetkilendirilmiştir. Belirli alanda uzmanlaşmış kişilerin o alandaki uyuşmazlıkları en iyi şekilde çözümleyecek olmaları göz önüne alındığında, Osmanlı Devletỉnin bu uygulaması da adaletin tesisi bakımından önemlidir. Yine Osmanlının farklı yörelerindeki kadılıklarda gece vakti görev yapan gece naiblerinin bulunması bu hususu desteklemektedir.

Naibler tıpkı kadılar gibi yapmış oldukları işlemlerden alınan harçlarla geçimlerini sağlamıştır. Örneğin Fatih Sultan Mehmet döneminde naiblerin itlakname düzenlediklerinde bir akçe, nikah kıydıklarında beş akçe, hüccetlerde bir akçe alacakları düzenlenmiştir. Naiblerin işlemler üzerinden alacağı miktarlar zaman içerisinde değişmiş, 16. Yüzyıl itibariyle kanunlarda belirlenen bedeller 19. Yüzyıla kadar değişmeden uygulanmıştır.

III. Selim döneminden itibaren adli teşkilattaki bozulmanın önüne geçmek ve naiblik kurumunu iyileştirmek amaçlı çeşitli düzenlemeler yapılmıştır. 1838 yılında çıkarılan Tarik-i İlmiyeye Mahsus Ceza Kanunname-i Hümayunu ile kadılık yapanlar ve yapacak olanlar için sınav getirilmiştir. Tanzimat döneminde kurulan 1855 tarihli Muallimhane-i Nüvvab ile nitelikli naibler yetiştirilmesi amaçlanmıştır. Yine 1855 tarihli Nüvvab Nizamnamesi ile naiblerin atama ve azilleri tekrar düzenlenmiştir. Mahkemeler beş grupta sınıflandırılmış ve naibler yeterliliklerine göre bu mahkemelerde görevlendirilmiştir. Fakat yapılan düzenlemeler adli teşkilattaki bozulmayı istenilen derecede düzeltmeye yetmemiştir. Tanzimat Dönemi itibariyle kadıların yerini naib almaya başlamış ve hakimler naib sıfatıyla anılmıştır. 1915 yılında naib tayin etme usulü sona erdirilmiş, Cumhuriyet döneminde şeriye mahkemeleri ile birlikte naiblik kurumu da ortadan kaldırılmıştır.

Osmanlı Devleti adli teşkilatında önemli bir yere sahip olan naiblik kurumu, görev yaptıkları yörelerden atanmaları, yeterli donanıma sahip olmamalarına rağmen ulema çocukları arasından atanmaları, kimi zaman çıkar amaçlı kimi zaman korku sebebiyle zulme ortak olmaları, çıkar amaçlı kanuna aykırı hareket etmeleri, sıklıkla kendi yerlerine naib atamaları, naibliğin iltizam usulü satılması gibi sebeplerle yozlaşmaya yüz tutmuştur. Özellikle naibliklerin iltizam usulü ile satılması, devletin içine girdiği ekonomik zorluklardan kaynaklanmıştır. Görüldüğü üzere söz konusu yozlaşma, naiblik kurumunun kendisinden değil, uygulanmasındaki usulsüzlüklerden kaynaklanmıştır. Zira kadı yardımcısı sıfatıyla görev yapan naib, adli ve idari işleri yürüterek kadının işini kolaylaştırmış, gece vakti mahkemelerde görev alarak adaletin kısa sürede tecelli 
etmesinde önemli rol oynamıştır. Özellikle İstanbul'da belirli alanlarda idari işleri yürütmekle görevli olan naibler bu alanlardaki uyuşmazlıkları da çözerek uzmanlaştıkları konularda adaleti sağlamışlardır. Fakat kadı derecesinde eğitim almamış naiblerin kadı yerine atanarak kadının sahip olduğu tüm yetki ve görevlere sahip olmuş olması, hukukun uygulanmasında kaçınılmaz olarak sorun yaratmıştır. Bu anlamda naiblik kurumu, ekonominin iyi olduğu, naiblerin gerekli eğitimi alanlar arasından usulüne uygun atandığı ve naiblerin görevlerini layıkıyla yaptığı dönemlerde, adli teşkilatta hâkimin önemli bir yardımcısı olmuş, adli işlerin görülmesini kolaylaştırmış, hızlandırmış, adaletin tecellisinde önemli rol oynamıştır. Bir başka deyişle naiblik kurumu, usulüne uygun yönetildiğinde adli teşkilata yarar sağlamıştır. 


\section{KAYNAKÇA}

BOA, 3 Numaralı Mühimme Defteri

BOA, 5 Numaralı Mühimme Defteri

BOA, 6 Numaralı Mühimme Defteri

BOA, 7 Numaralı Mühimme Defteri I

BOA, 7 Numaralı Mühimme Defteri II

BOA, 7 Numaralı Mühimme Defteri III

BOA, 12 Numaralı Mühimme Defteri I

Akdağ, Mustafa (2018) Türkiye’nin İktisadi ve İçtimai Tarihi (1453-1559), 4. Baskı, İstanbul, Yapı Kredi Yayınları.

Akgündüz, Ahmed (1990) Osmanlı Kanunnameleri ve Hukuki Tahlilleri, I. Kitap, İstanbul, Fey Vakfi Yayınları.

Akiba, Jun (2005) "From Kadı to Naib: Reorganization of the Ottoman Sharia Judiciary in the Tanzimat Period”, Frontiers of Ottoman Studies, ed. Colin Imber and Keiko Kiyotaki, vol. 1, s. 43-60.

Akkutay, Ülker (1984) Enderun Mektebi, Ankara, Gazi Üniversitesi Yayınları.

Akman, Mehmet (2004) Osmanlı Devleti'nde Ceza Yargılaması, 1. Baskı, İstanbul, Eren Yayıncllik.

Aköz Alaaddin (1996) “XVI. Asrın İlk Yarısında Aladağ Kazası (1501-1540)”, Osmanlı Araştırmaları Dergisi, Sayı: 16, s. 67-84.

Aköz, Alaaddin (2006) Kanuni Devrine Ait 939-941/1532-1535 Tarihli Larende (Karaman) Şer'iye Sicili, 2. Basım, Konya, Tablet Kitabevi.

Akşin Somel, Selçuk (1996) “Osman Nuri Paşa'nın 17 Temmuz 1885 Tarihli Hicaz Raporu”, Tarih Araştırmaları Dergisi, Cilt: 18, Sayı: 29, s. 1-38.

Akyılmaz, Gül (2015) Siyasi Tarih, 1. Baskı, Ankara, Seçkin Yayınevi.

Alan, Ercan (2013) "Kadıasker Ruznamçe Defterlerine Göre XVII. Yüzyılda Rumeli'de Kaza Teşkilatı ve Kadılar”, Güney-Doğu Avrupa Araştırmaları Dergisi, Sayı:23, s. 53-97.

Anıl, Yaşar Şahin (1993) Osmanlı’da Kadılık, 1. Basım, İstanbul, İletişim Yayınları.

Arık, Feda Şamil (1997) “Osmanlılarda Kadılık Müessesesi 1”, Ankara Üniversitesi Osmanlı Tarihi Araştırma ve Uygulama Merkezi Dergisi, Sayı: 8, s. 1-71.

Aşık Paşazade (2003) Osmanoğulları'nın Tarihi, Hazırlayanlar: Yavuz, Kemal/Saraç, Yekta, İstanbul, K Kitaplığı Yayınları.

Avcı, Casim (2006) İslam Ansiklopedisi, "Naib", Türkiye Diyanet Vakfı İslam Araştırmaları Merkezi, Cilt: 32, s. 311-312.

Avcı, Mustafa (2012) Türk Hukuk Tarihi Dersleri, 1. Baskı, Konya, Mimoza Yayınları. 
Aydın, Mehmet Akif, "Osmanlıda Hukuk": İhsanoğlu, Ekmeleddin (Editör) (1994) Osmanlı Devleti ve Medeniyeti Tarihi, 1. Bası, İstanbul, Yıldız Matbaacılık, s. 375-438.

Aydın, Mehmet Akif (2014) Türk Hukuk Tarihi, 12. Bası, İstanbul, Beta.

Aykanat, Mehmet (2018) “Klasik Dönemde Osmanlı Devleti'nde Hâkim Adaylığı: Mülazemet”, Türkiye Adalet Akademisi Dergisi, Sayı: 34, s. 165-188.

Bal, Emel Bengü (2016) “Tanzimattan Sonra Kadı ve Naip Yetiştirmek Amacıyla Kurulan Okul: Mekteb-i Nüvvab”, (Yayımlanmamış Yüksek Lisans Tezi), Sakarya Üniversitesi Sosyal Bilimler Enstitüsü.

Bayındır, Abdulaziz (2015) İslam Muhakeme Hukuku, 2. Baskı, İstanbul, Süleymaniye Vakfı Yayınları.

Bazna, Yalçın (2013) “1951/137 Numaralı (1810-1811 M. Tarihli) Trabzon Şer'iyye Sicili”, (Yayımlanmamış Yüksek Lisans Tezi), Fırat Üniversitesi Sosyal Bilimler Enstitüsü.

Beyazıt, Yasemin (2009) "Osmanlı İlmiyye Tarîkinde İstihdam ve Hareket: Rumeli Kadıaskerliği Ruznâmçeleri Üzerine Bir Tahlil Denemesi (XVI. Yüzyıl)”, (Yayımlanmamış Doktora Tezi), Ankara Üniversitesi Sosyal Bilimler Enstitüsü.

Cin, Halil/Akgündüz, Ahmed (1995) Türk Hukuk Tarihi, 3. Baskı, İstanbul, Osmanlı Araştırmaları Vakfı Yayınları.

Cin, Halil/Akyılmaz, Gül (2013) Türk Hukuk Tarihi, 5. Baskı, Konya, Sayram Yayınları.

Çadırcı, Musa (1981) “Tanzimat'ın İlanı Sıralarında Osmanlı İmparatorluğunda Kadılık Kurumu ve 1838 Tarihli Tarık-1 İlmıye'ye Dair Ceza Kanunnamesi”, Tarih Araştırmaları Dergisi, Cilt: 14, Sayı: 25, s. 139-161.

Çadırcı, Musa (1991) Tanzimat Döneminde Anadolu Kentlerinin Sosyal ve Ekonomik Yapıları, 1. Baskı, Ankara, Atatürk Kültür, Dil ve Tarih Yüksek Kurumu Türk Tarih Kurumu Yayınları.

Demir, Aydoğan (1994) “Bayburt Ulu Camii’nde Bir Osmanlı Ferman Kitabesi, Osmanlı Devleti'nde Naiplik”, Tarih ve Toplum, Sayı: 132, s. 41-58.

Devellioğlu, Ferit (2017) Osmanlıca-Türkçe Ansiklopedik Lugat, 33. Baskı, Ankara, Aydın Kitabevi Yayınları.

Doğan, Recai (1997) “Osmanlı Eğitim Kurumları ve Eğitimde İlk Yenileşme Hareketlerinin Batılılaşma Açısından Tahlili”, Ankara Üniversitesi İlahiyat Fakültesi Dergisi, Cilt: 37, Sayı: 1, s. 407-442.

Ekinci, Ekrem Buğra (2001) Ateş İstidası İslam-Osmanlı Hukukunda Mahkeme Kararlarının Kontrolü, İstanbul, Filiz Kitabevi.

Ekinci, Ekrem Buğra (2008) Osmanlı Hukuku, 1. Baskı, İstanbul, Arı Sanat Yayınevi.

Ekinci, Ekrem Buğra, Prof. Dr. Ekrem Buğra Ekinci, “Osmanlı Medreseleri”, $<$ http://www.ekrembugraekinci.com/makale.asp?id=931>, s.e.t. 23.12.2018. 
Erdoğdu, İbrahim (2014) “17. Yüzyılın İkinci Yarısında Taşrada Yargı Uygulamaları: Harput Örneğinde Hakimü’ş Şer”, Fırat Üniversitesi Harput Araştırmaları Dergisi, Cilt: 1, Sayı: 2, s. 49-86.

Fendoğlu, Hasan Tahsin (2000) Türk Hukuk Tarihi, 1. Baskı, İstanbul, Filiz Kitabevi.

Feyzioğlu, Hamiyet Sezer/Kılıç, Selda (2005) “Tanzimat Arifesinde Kadılık-Naiplik Kurumu”, Tarih Araştırmaları Dergisi, Cilt: 24, Sayı: 38, s. 31-53.

Güzelbey, Cemil Cahit/Yetkin, Hulusi “Gaziantep Şer’i Mahkeme Sicillerinden Örnekler”, (1970) Cilt: 81-141, Miladi 1729-1825, Gaziantep Kültür Derneği Kitap ve Broşür Yayınları, Sayı: 55.

Gür, A. Refik (2015) Osmanlı İmparatorluğu'nda Kadılık Müessesesi, Hazırlayan: Aryol, M. Nihat, İstanbul, Türkiye İş Bankası Kültür Yayınları.

Halaçoğlu, Yusuf (2014) XIV-XVII Yüzyıllarda Osmanlılarda Devlet Teşkilatı ve Sosyal Yapı, 7. Baskı, Ankara, Atatürk Kültür, Dil ve Tarih Yüksek Kurumu Türk Tarih Kurumu Yayınları.

İnalcık, Halil (1967) “Adaletnameler”, Belgeler, Ankara, Türk Tarih Kurumu, Cilt: 2, Sayı: 3-4, s. $49-145$.

İpşirli, Mehmet (1991) İslam Ansiklopedisi, “Bab Mahkemesi”, Türkiye Diyanet Vakfı İslam Araştırmaları Merkezi, Cilt: 4, s. 362.

İpşirli, Mehmet (2003) İslam Ansiklopedisi, "Medrese”, Türkiye Diyanet Vakfı İslam Araştırmaları Merkezi, Cilt: 28, s. 327-333.

İpşirli, Mehmet (2006) İslam Ansiklopedisi, “Naib”, Türkiye Diyanet Vakfı İslam Araştırmaları Merkezi, Cilt: 32, s. 312-313.

Kılıç, Cihan (2017) "XVII. Yüzyılın İkinci Yarısında Osmanlı İlmiye Teşkilatında İstihdam ve Hareket (Anadolu Kadıaskerliği Örneği)”, (Yayımlanmamış Doktora Tezi), Yıldırım Beyazıt Üniversitesi Sosyal Bilimler Enstitüsü.

Kılınç, Ahmet (2011) “İdam Cezasının Tanzimat Dönemi Osmanlı Hukukundaki Görünümüne İlişkin Birkaç Kaynak ve Bu Kaynakların Tahlili”, Türk Hukuk Tarihi Araştırmaları, Sayı: 11, s. 33-62.

Kılınç, Ahmet (2016) "Yıldırım Bayezid Han’ın Devlet Yönetimine Işık Tutan İki Osmanlıca Makale ve Tahlilleri”, Yıldırım Beyazıt Hukuk Dergisi, Sayı: 1, s. 1-24.

Kuru, Levent (2016) “Kazasker Ruznamçelerine Göre 18. Yüzyılın İlk Yarısında Rumeli'de Kadılık Müessesesi”, (Yayımlanmamış Doktora Tezi), Marmara Üniversitesi Türkiyat Araştırmaları Enstitüsü.

Ongan, Halit (2014) Ankara’nın İki Numaralı Şer’iye Sicili, 2. Baskı, Ankara, Atatürk Kültür, Dil ve Tarih Yüksek Kurumu Türk Tarih Kurumu Yayınları.

Orak, Muhammet Ali (Editör) (2014) Konya Kadı Sicili (1070-1071/1659-1661) Defter 10, 14, Konya, Konya Büyükşehir Belediyesi Kültür Yayınları. 
Ortaylı, İlber (2016) Hukuk ve İdare Adamı Olarak Osmanlı Devleti'nde Kadı, 2. Baskı, İstanbul, Kronik.

Saydam, Abdullah (2005) “Trabzon'un İdari Yapısı ve Yenileşme Zarureti (1793-1851)”, Ankara Üniversitesi Osmanlı Tarihi Araştırma ve Uygulama Merkezi Dergisi, Sayı: 18, s. 285317.

Seyitdanlığlu, Mehmet (1999) Tanzimat Devrinde Meclis-i Vala (1838-1868), 1. Bask1, Ankara, Atatürk Kültür, Dil ve Tarih Yüksek Kurumu Türk Tarih Kurumu Yayınları.

Şafakcı, Hamit (2016) "Belviran Kazası Tekke ve Zaviyeleri (1476-1876)”, Vakıflar Dergisi, Say1: 45 , s. 59-89.

Şer'iye Sicilleri Seçme Hükümler (1989) II. Cilt, İstanbul, Türk Dünyası Araştırmaları Vakfı.

Unan, Fahri (2004) İslam Ansiklopedisi, "Mevleviyet”, Türkiye Diyanet Vakfı İslam Araştırmalar1 Merkezi, Cilt: 29, s. 467-468.

Uzunçarşılı, İsmail Hakkı (2014) Osmanlı Devleti’nin İlmiye Teşkilatı, 4. Baskı, Ankara, Atatürk Kültür, Dil ve Tarih Yüksek Kurumu Türk Tarih Kurumu Yayınları.

Üçok, Coşkun/Mumcu, Ahmet/Bozkurt, Gülnihal (2017) Türk Hukuk Tarihi, 19. Baskı, Ankara, Turhan Kitabevi.

Ünal Özkorkut, Nevin (2008) "Yarg1 Bağımsızlı̆̆1 Açısından Osmanlı'da ve Günümüz Türkiyesi’nde Yargıya Genel Bir Bakış”, Ankara Üniversitesi Hukuk Fakültesi Dergisi, Cilt: 57, Sayı: 1, s. 225-242.

Yılmazçelik, İbrahim (2012) "XIX. Yüzyılda Osmanlı Taşra Teşkilatının Önemli Merkezlerinden Biri Olan Diyarbakır’da Bazı Görevlilerle İlgili Tespitler”, Ankara Üniversitesi Osmanlı Tarihi Araştırma ve Uygulama Merkezi Dergisi, Sayı: 31, s. 225-242.

Yurdakul, İlhami (2016) İslam Ansiklopedisi, "Mekteb-i Nüvvab", Türkiye Diyanet Vakfı İslam Araştırmaları Merkezi, Cilt: Ek-2, s. 242-243.

Yurtseven, Yılmaz (2006) “Osmanlı Devleti’nde Siyasal İktidarın Meşruluk Temelleri”, (Yayımlanmamış Doktora Tezi), Selçuk Üniversitesi Sosyal Bilimler Enstitüsü. 